\title{
Glycerol waste to value added products and its potential applications
}

\author{
Chaitanya Reddy Chilakamarry ${ }^{1}$ - A. M. Mimi Sakinah ${ }^{1}$ - A. W. Zularisam ${ }^{2} \cdot$ Ashok Pandey $^{3}$
}

Received: 30 April 2021 / Revised: 27 May 2021 / Accepted: 1 June 2021 / Published online: 7 June 2021

(c) Jiangnan University 2021

\begin{abstract}
The rapid industrial and economic development runs on fossil fuel and other energy sources. Limited oil reserves, environmental issues, and high transportation costs lead towards carbon unbiased renewable and sustainable fuel. Compared to other carbon-based fuels, biodiesel is attracted worldwide as a biofuel for the reduction of global dependence on fossil fuels and the greenhouse effect. During biodiesel production, approximately $10 \%$ of glycerol is formed in the transesterification process in a biodiesel plant. The ditching of crude glycerol is important as it contains salt, free fatty acids, and methanol that cause contamination of soil and creates environmental challenges for researchers. However, the excessive cost of crude glycerol refining and market capacity encourage the biodiesel industries for developing a new idea for utilising and produced extra sources of income and treat biodiesel waste. This review focuses on the significance of crude glycerol in the value-added utilisation and conversion to bioethanol by a fermentation process and describes the opportunities of glycerol in various applications.
\end{abstract}

\section{Graphic abstract}

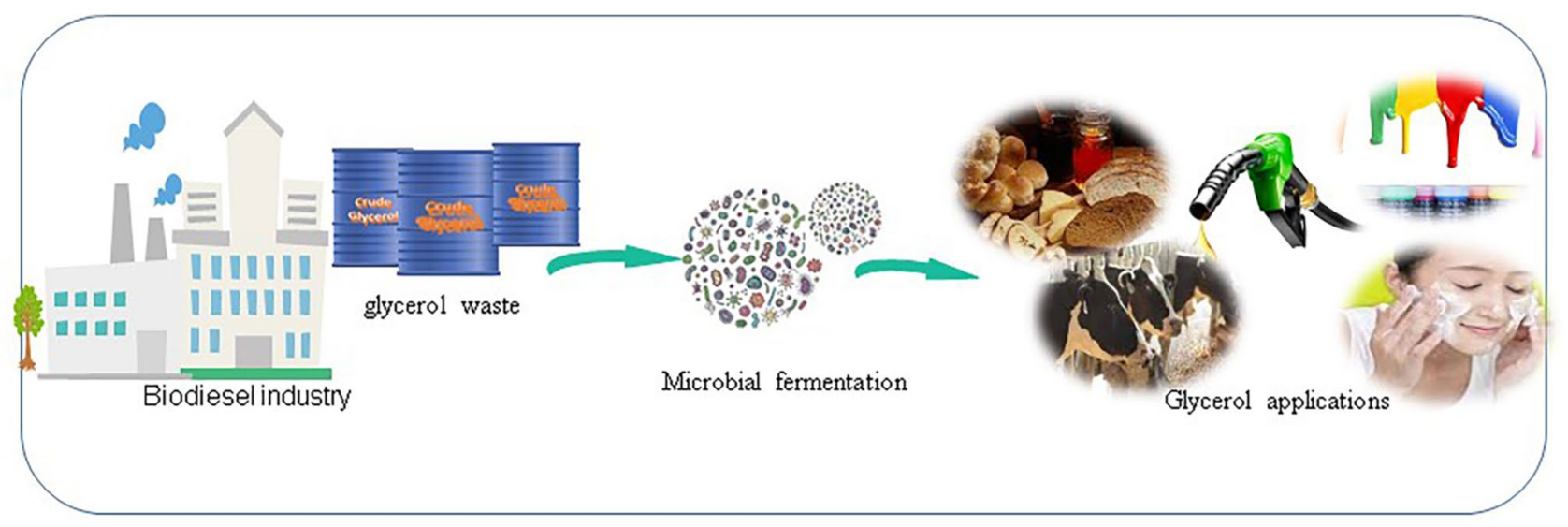

Keywords Crude glycerol $\cdot$ Bioethanol $\cdot$ Biofuel $\cdot$ Valuable products

A. M. Mimi Sakinah

mimi@ump.edu.my

1 Faculty of Chemical and Process Engineering Technology, Universiti Malaysia Pahang, Gambang, Kuantan, Malaysia 26300

2 Faculty of Civil Engineering Technology, Universiti Malaysia Pahang, Gambang, Kuantan, Malaysia 26300

3 Centre for Innovation and Translational Research, CSIR-Indian Institute of Toxicology Research, Lucknow 226 001, India

\section{Introduction}

As fossil fuels worldwide are becoming increasingly concerned, the need for renewable energy sources has become more urgent than ever due to the increase in energy demand, lack of global oil supply, and changes in the climate [1]. Energy sources are rationed worldwide. There are no energy shortages in developed countries whereas developing countries like Malaysia, China, India, Thailand, etc. need more 
energy to boost development programs. However, most nations either developed or developing countries are trying to promote the use of renewables to meet their rising energy demand and to decrease import fuel dependence and partly to seek an agreement to minimise greenhouse gas emissions (GHGs) [2]. According to the International energy outlook (IEO), at present, the most used source of energy is liquid fuels which are approximately 205 quadrillions Btu whereas renewables are 120 quadrillions Btu and are expected to use renewables more than petroleum worldwide till 2050 as shown in Fig. 1 [3].

The EIA (energy information administration) issued an annual energy outlook of 2021 and forecasted the biofuel usage will steadily increase by 2050 . Although the COVID19 pandemic affected the market for all liquid fuels last year, the EIA states that biofuel consumption has not fallen as much as petrol-based fuels. EIA plans to raise and steadily expand the percentage of biofuel mixed with the US transportation fuel pool by 2050. The production of biodiesel in the reference case is expected to increase slightly, maintaining a steady supply level by 2050 . The output of renewable diesel is expected to rise at a higher pace. In the later years of the prediction era, ethanol consumption is projected to return to pre-COVID levels, which will continue to increase until 2050 because the higher ethanol blends are being introduced into the road transport fuel EIA. Biodiesel production is bound to grow by $0.5 \%$ by 2050 , reaching 130,000 barrels a day.

Many researchers focused on the expansion of biodiesel due to eco-friendly fuel. The use of biodiesel as an alternative fuel to Petro diesel is seen as a significant transitional strategy in the quest for new sources of fuel [4]. Biodiesel is commonly used as a fuel substitute, is made from a range of renewable feedstocks, including plant oils, animal fats, and reused oil [5]. Particularly the biodiesel produced from plant oil from babassu, canola, castor bean, crambe, jatropha, lupine, palm oil, seed radish, peanut, sunflowers, soybeans, peanut, and macauba. It is also formed from cooking oil waste and photosynthetic algae, respectively [6]. Animal fats and plant oils containing fatty acids are transformed into fatty acid methyl or ethyl esters in a transesterification reaction during the biodiesel production process.

The primary byproduct in biodiesel processing is larger quantities of crude glycerol, representing approximately $10 \%$ of total biodiesel [7]. About $10 \mathrm{lb}$ of biodiesel produces $1.10 \mathrm{lb}$ of glycerol [8]. The rise in the price of biodiesel is increasing from $0.015 £$ /liter and the price decrease by $0.079 \mathrm{f} / \mathrm{Lb}$. in the sale of glycerol. With the growth of biodiesel plants, increased quantities of rough glycerol are produced, which has affected the market price of glycerol and the economy of biodiesel production [9]. To mitigate this effect, a range of approaches of crude glycerol like direct burning as heating oil, purification for commercial glycerol sale, hydrogen reforming, and microbial conversion into valuable products [10]. The first three solutions that use further energy are less profitable, require off-gas processing for direct combustion, and control toxic gas emissions [11].

Further purification procedures to eliminate impurities such as water, methanol, soap, and fat are necessary to increase glycerol concentration by over $80 \%$ before marketing with low-value crude glycerol, ranging from 35 to $50 \%$. Not only has this surplus crude glycerol significantly affected consumer prices, but it also has caused environmental problems because treatment is needed before discharge into the atmosphere [12].

Crude glycerol upgrading to valuable products impairs a significant impact on the biodiesel economy [13]. It also falls under the fourth-generation biofuel approach to produce minimal waste [14]. Clearing raw glycerol is a tedious approach, and thus the use of raw glycerol is intact as a source for any industrial product [15]. The study of new applications for crude glycerol is necessary to reduce the projected surplus supply. Therefore, various outlets were tested for the disposal and use of crude glycerol. Major biodiesel producers have upgraded crude glycerol to pure glycerol through expensive purification processes [16]. However, alternatives to use crude glycerol as the main feedstock to generate value for money products employing chemical conversion and thermochemical/biological conversion are promising for affordable output [17]. Biological methods
Fig. 1 Most used energy source by 2050

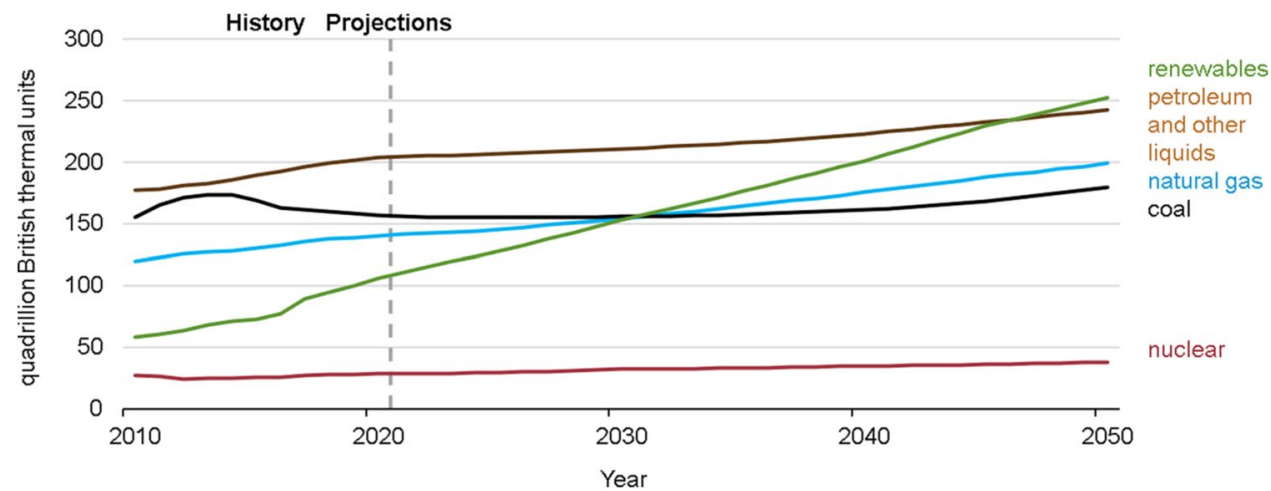


for converting crude glycerol into various valuable chemicals and fuels like 1, 3-propanediol, hydrogen, citric acid, dihydroxyacetone, and ethanol were considerably developed [18]. This review focuses on the industrial byproduct of crude glycerol waste from the biodiesel industry. The crude glycerol bioconversion into ethanol is described and valuable products from glycerol with various applications are reviewed.

\section{Glycerol production from the biodiesel industry}

In conjunction with the efforts to ensure a sustainable expansion of the biodiesel industry, a necessary policy for renewable diesel could be built to cover the mandates, tax incentives, and subsidiaries in the future. This campaign widely opened biodiesel's prospects to globally replace fossil fuels as the world's leading energy source.

Biodiesel is produced from the following methods like blending, micro emulsification, pyrolysis, and transesterification process as shown in Fig. 2. In the blending process, the ratio of $10-40 \%(w / w)$ preheated vegetable/animal oils were blended with petro-diesel. The resulting oil-diesel mixture is used in the diesel engine. The advantage of this process does not require chemicals and no requirement for engine modifications. Micro emulsification is a pollutionfree and simple process in which the vegetable or animal oil is solubilised in solvent (alcohol) and surfactant until required viscosity was obtained [19].

In the pyrolysis process, vegetable/animal oils were preheated and broken down at high temperatures above $350{ }^{\circ} \mathrm{C}$ in the presence or absence of the catalyst. Various products, including gas and liquid, were analysed to determine the exact product according to their boiling temperature range. The process is a practical, waste-free, and simple process with no washing, drying, and filtering [4]. The commonly used method is transesterification and as shown in Fig. 3.

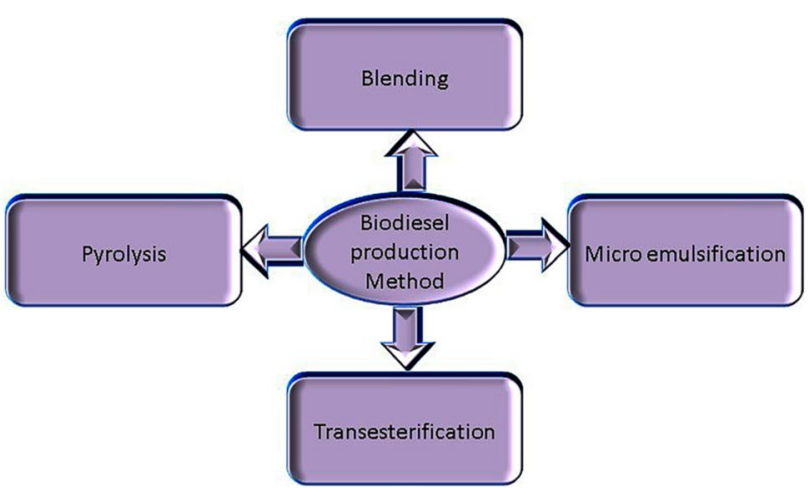

Fig. 2 Methods for biodiesel production

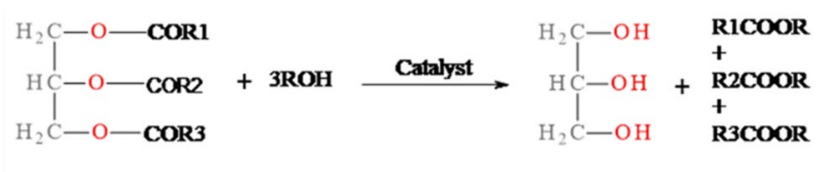

$\mathrm{R} 1, \mathrm{R} 2, \mathrm{R} 3=$ long chain

hydrocarbon

Glycerol Biodiesel

Fig. 3 Biodiesel production by transesterification process

Transesterification is one of the most economic processes with high biodiesel yield and therefore the most adaptive method for commercial production of biodiesel. The vegetable/animal oils and fats were reacted with alcohol and alkali or acid catalyst, then the mixture of methyl/ethyl esters (biodiesel) and glycerol by-product undergo separation and purification steps before further usage. The biodiesel production approaches with pros and cons are summarised in Table 1 [13].

Biodiesel is essentially derived from the triglyceride transesterification process in which $90 \mathrm{wt}$ percent of methyl ester (biodiesel) and 10wt percent of glycerol are produced [20]. The selection of catalysts depends on the fatty acid content of oil. Alkali catalysts improve the process to achieve a higher biodiesel yield [21]. Alkaline catalysed transesterification has several advantages like a fast reaction rate, which requires less time, and an easy setup than acid catalysts. [22].

Glycerol is traditionally obtained from four different processes, i.e. soap production, fatty acids production, fatty esters production, and microbial fermentation. For over a century, the reactions of vegetable oils and animal fats directly transformed into glycerol and methyl esters have been identified. Transesterification of triglycerides like rapeseed, palm, soybean, and sunflower oils has become important for manufacturing biodiesel fuel of high quality. The key focus of development is currently on glycerol byproducts from the biodiesel industry. Typically, three mol of methanol reacts to the formation of methyl esters and glycerol in three steps with the presence of a catalyst. In the first step, methanol reacts with triglycerides to form diglycerides and methyl esters. Later, methanol reacts again with diglycerides to monoglycerides and methyl ester. These monoglycerides react with methanol again and eventually form glycerol and methyl esters [23, 24]. According to Alexandre et al., the schematic summary of the generation of glycerol and its alternative route is shown in Fig. 4 [17]. Glycerol is refined from unrefined glycerol is an expensive process is used in the chemical, textile, pharmaceutical, and food industries. An alternative application of unrefined glycerol for fuel additives, development of fuel cells, to produce hydrogen, methanol, and ethanol, co-digestion and co-gasofication, and for the waste treatment. 
Table 1 Biodiesel production from various approaches with pros and cons

\begin{tabular}{llll}
\hline S.no & Method & Pro's & Con's \\
\hline 1 & Blending & $\begin{array}{c}\text { No chemical process, No technical modification and } \\
\text { Easy implementation }\end{array}$ & $\begin{array}{c}\text { Unstable, an Increase in the vegetable/animal oil portion } \\
\text { led to an improper pattern of spraying } \\
\text { Poor atomization, incomplete combustion of fuel, and } \\
\text { difficulty handling conventional engines }\end{array}$ \\
$\begin{array}{l}\text { High viscosity, Less volatility, Low stability and lead to } \\
\text { sticking, incomplete combustion, and carbon deposition } \\
\text { High installation costs, high carbon residues produce less } \\
\text { purity, high-temperature clinker is required }\end{array}$ \\
Pyrolysis & Transesterification & $\begin{array}{c}\text { The production of biodiesel is comparable to diesel, } \\
\text { favorable for industrial manufacturing }\end{array}$ & $\begin{array}{c}\text { With less conversion efficiency, the catalyst cannot be } \\
\text { reused }\end{array}$ \\
\hline
\end{tabular}

Fig. 4 Generation of glycerol through transesterification

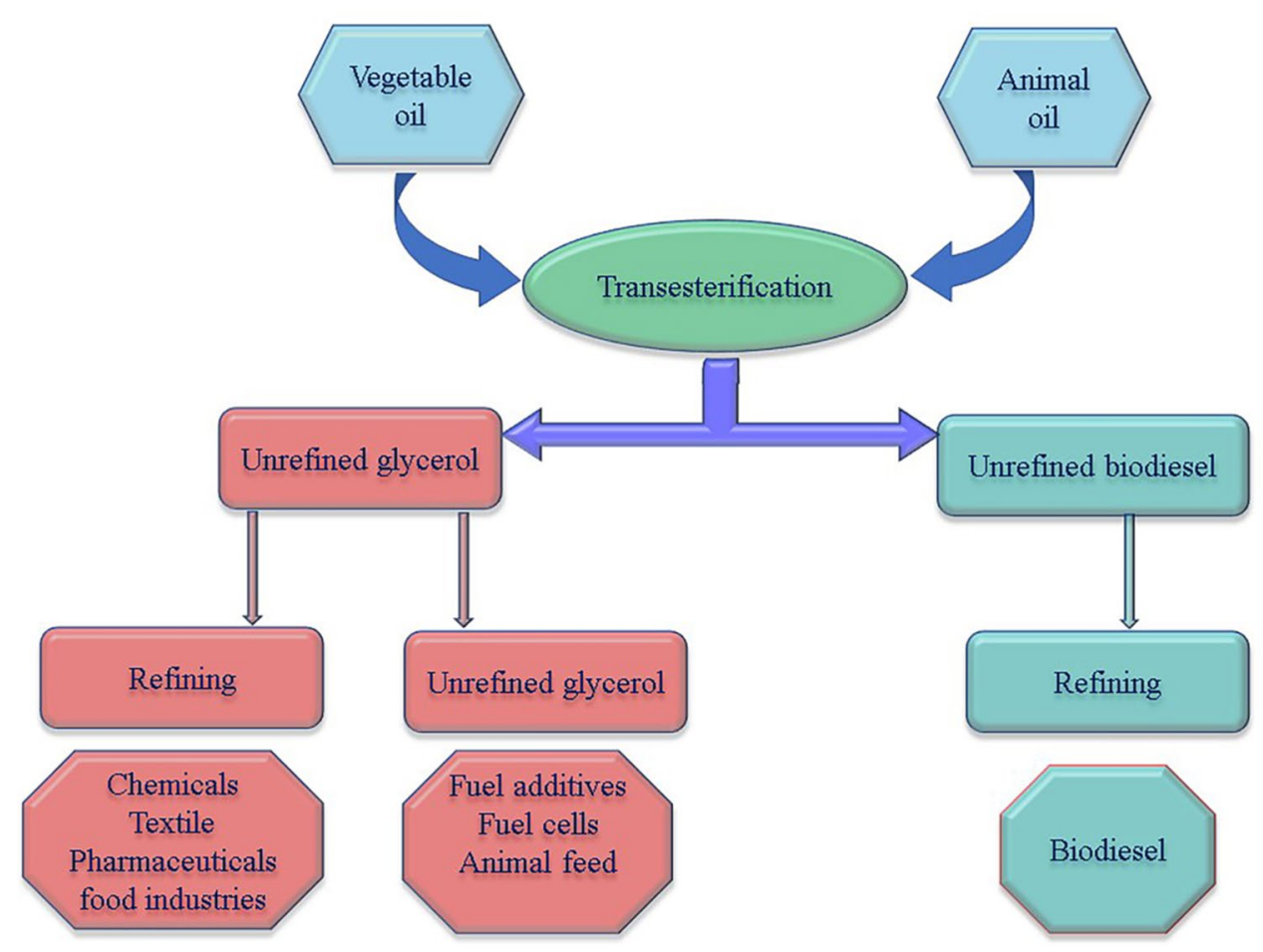

In literature, the expressions of glycerol, glycerine, glycerin, and 1,2,3-propanetriol are preferred to use. The word glycerol usually refers to the pure substance. Though glycerine refers to commercial products containing more than $95 \%$ glycerol solutions in water. These products vary in glycerol content, colour, odour, and impurity traces. Crude-glycerol contains catalysts, dissolved salts, fatty acids, water, and $70-80 \%$ glycerol in the biodiesel production process [25]. Hydrolysis, saponification, and the byproduct of transesterification reaction of animal fats and vegetable oils are the most popular routes for glycerol synthesis [26]. At the same time, other methods such as the fermentation process and carbohydrate hydrogenolysis are non-industrial. The alkyl esters were obtained from the transesterification of animal fats and vegetable oils with alcohol. Primarily the simple catalysts are the key route in the biodiesel industry as a byproduct single glycerol molecule is produced for each of three methyl or ethyl ester molecules that form the basis of biodiesel [27].

According to SDA's glycerine and oleochemical Division, over 1500 glycerol applications include hundreds of food and foam categories, as well as cosmetics and pharmaceutical [28]. The vast array of applications reflects the broad range of chemical reactions of glycerol for synthetic precursors to obtain more valuable products with insertion choice in various fields is described in Fig. 5. which illustrates the main chemical reactions of glycerol transformation. Crude glycerol found from biodiesel synthesis contains alcohol (particularly methanol), catalysts, free fatty acids, mono, diand triacylglycerols, salts, and water contents which differ 
Fig. 5 Valuable products formed from the chemical paths

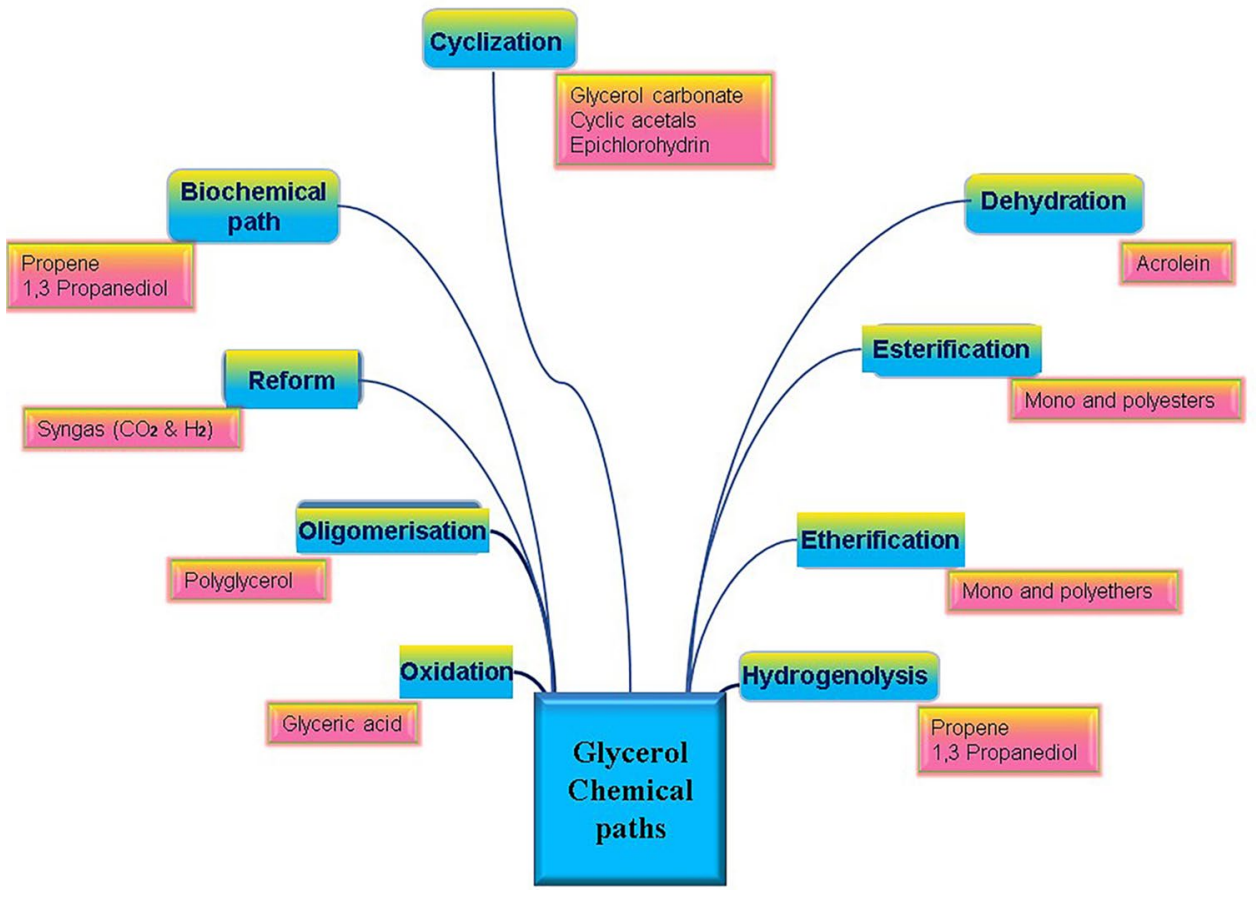

with the usage of raw material, catalytic process, and the stages of biodiesel preparation and purification [29].

A significant characteristic feature of the glycerol chain link with the chain of the biodiesel industry. The increase in biodiesel manufacture resulted in substantial surpluses of glycerol, which have a negative impact on its marketplace. The market value for crude glycerol from $0.065 £$ and $0.072 £ /$ Lb. However, the price of pure glycerol is between 0.22 and $0.37 £ / \mathrm{Lb}$. Approximate crude glycerol production will reach 50 billion liters in 2021 [30].

The biodiesel industry produces energy and sells the commodity that lacks the treatment with crude glycerol. Crude glycerol by combustion and uncontrolled burning leads to severe risks to human health due to the formation of unsaturated aldehyde [31].

Pure glycerol found on the market is refined and includes less than 5\% impurities. This is not the case with crude glycerol produced from the production of biodiesel. Crude glycerol is either produced by oil saponification (16\% impurities), hydrolysis (10-12\% impurities), and transesterification (25-30\% impurities) [32]. The market for glycerol previously had a strong connection with demand patterns in the medicinal, food products, cosmetics, polymer, and other chemical industries. The applications of glycerol in drugs and pharmaceuticals for the treatment of wounds, skin burns, and skin grafts, also acts as holding agents for tablets and in cough syrups, glycerol is utilised in the blood bank to maintain blood cells from freezing, personal care products like moisturiser cream, cosmetics for the skin, mouth wash, and soap. Glycerol is used to preserve food, sweetener and acts as thickening agents in distilled spirits. The various application of glycerol is shown in Fig. 6 [6].

Pinheiro categorised the emergence of two consumer markets for glycerol. First, is the existing market demanded a higher purity product by market standard requirements primarily as additives for food, pharmaceuticals, and cosmetics. Second the use of biodiesel crude glycerol for the transformation of products or chemical intermediates. This market is characterised by higher product volume demand, lower quality standards, and lesser costs [6].

Biodiesel industries concentrate on the technical challenges of biodiesel manufacture, storage, and treatment of crude glycerol waste. This implies enterprise strategies creating innovative claims to enable the extra value and the exploration of new markets. This fact does not support technical advancement concerning the byproduct of crude glycerol by biodiesel production firms. However, there is a trend for non-biodiesel companies to seek technical solutions in the utilisation of crude glycerol for other valuable products [33].

Glycerin is available for various applications depends on chemical and physical characteristics like less volatile nature, hygroscopic, elastic, softness and flexibility, solvent strength, solubility, high miscibility, materials compatibility, stability, high viscosity, antifreeze property, no toxicity, and emollient quality. The application of crude glycerol is restricted due to its purity that affects physical, chemical, and biological properties lowering the metabolite concentration $[34,35]$. The crude glycerol has impurities in the form of inorganic salts. The higher levels of $\mathrm{Na}$ and $\mathrm{K}$ in 
Fig. 6 Various applications of glycerol

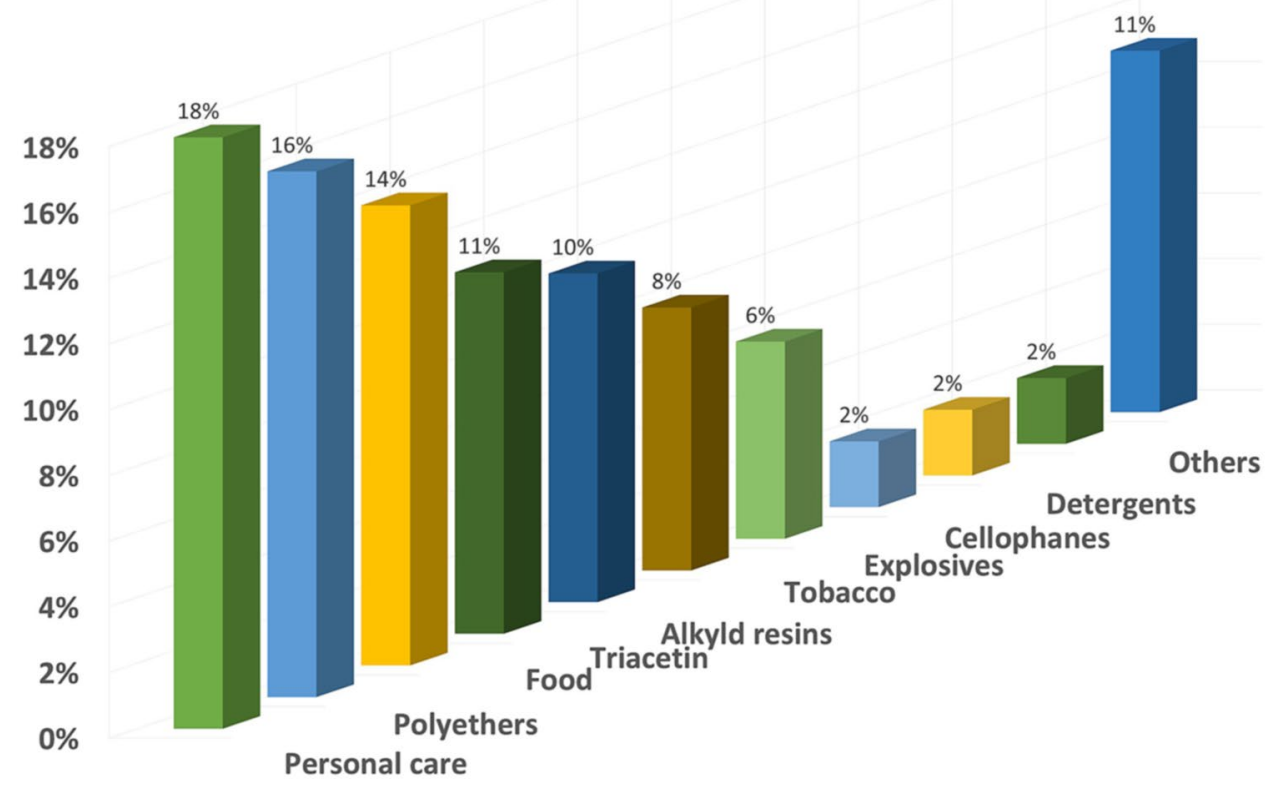

Drugs and pharmaceuticals

the diet result in electrolyte imbalance in animals. As the unregulated glycerol product from biodiesel affects animal metabolism. Methanol is one of the reactants in biodiesel production. The higher levels above $150 \mathrm{ppm}$ are unsafe for animal feed causing blindness by destruction of optical nerve [36].

\section{Metabolic pathway of glycerol}

Since crude glycerol is polluted with many biodiesel chemicals, purification is not economically advantageous. Autothermal reform of crude glycerol produces hydrogen, but greenhouse gas emissions are a matter of concern. Microbial fermentation is thus defined as an option that can benefit the metabolic pathways leading to the desired products (biohydrogen and bio alcohol), thus minimising the formation of other side products by using ideal conditions and proper micro-organisms [37]. Several microbes can aerobically metabolise glycerol and few microbes can anaerobically metabolise. Crude glycerol can be converted into valueadded products by Escherichia coli, Klebsiella, Enterobacter, Glucanobacter, Clostridium, Candida, Aspergillus is shown in Table 2.

Glycerol has a higher rate of reduction than sugars and is thus cheaper and more readily available. The almost exclusive synthesis of reduced products during glycerol fermentation represents a very reducible glycerol level compared to glucose fermentation. Conversion of glycerol to phosphoenolpyruvate or pyruvate is higher than glucose. The fermentation of glycerol produced ethanol and formic acid (or ethanol and hydrogen), for example, generated twice as much in total as glucose fermentation as half of the glucose was lost as carbon dioxide in glucose conversion [38]. Furthermore, the use of crude glycerol often alleviates the glucose effect of carbon catabolic repression in the case of glucose use. For carbon catabolite repression, a fastmetabolising source of carbon like glucose curbs the gene expression that encodes protein needed to use other sources of carbon like glycerol and lactose.

Glycerol is a small, uncharged symmetrical molecule. Development of a small number of metabolic routes for channelling by using glycerol as a terminal acceptor of electrons anaerobically to the central carbon for biomass and energy production. The first step in all pathways is the transportation of glycerol into the cell. Depending on the micro-organism, different modes of transport are used. Bacteria primarily use facilitated diffusion in the cell to glycerol network. The facilitator proteins are primarily simple permeases. For eukaryotes including yeasts $S$. cerevisiae and $Y$. lipolytica, glycerol is mainly taken up with Glycerol/H + antiportors via an active transport method.

Microbes utilise two key metabolic paths in which glycerol is converted to the necessary glycolytic mediates for cell 
Table 2 Crude glycerol conversion by a micro-organism into valuable products

\begin{tabular}{|c|c|c|c|c|c|}
\hline Micro-organism & Type of strain & Product formed & Yield or concentration & Productivity $(\mathrm{g} / \mathrm{L} / \mathrm{h})$ & References \\
\hline \multirow[t]{3}{*}{ Citrobacter } & C. freundii FMCC-B294 & 1,3 propanediol & $0.48 \mathrm{~mol} / \mathrm{mol}$ & $0.79 \mathrm{~g} / \mathrm{L} / \mathrm{h}$ & {$[41]$} \\
\hline & C. werkmonii DSM 17,579 & & $0.62 \mathrm{~mol} / \mathrm{mol}$ & $2.84 \mathrm{~g} / \mathrm{L} / \mathrm{h}$ & {$[50]$} \\
\hline & C. freudii $\mathrm{H} 3$ & Hydrogen & $0.94 \mathrm{~mol} / \mathrm{mol}$ & - & {$[51]$} \\
\hline \multirow[t]{6}{*}{ Clostridium } & C. pasteurianam (immobilised) & n-butanol & $0.43 \mathrm{~mol} / \mathrm{mol}$ & $0.074 \mathrm{~g} / \mathrm{L} / \mathrm{h}$ & {$[52]$} \\
\hline & Clostridium CT7 & & $11.8 \mathrm{~g} / \mathrm{L}$ & - & {$[53]$} \\
\hline & C. butyricum AKR102a & 1,3 propanediol & $0.63 \mathrm{~mol} / \mathrm{mol}$ & $3.3 \mathrm{~g} / \mathrm{L} / \mathrm{h}$ & {$[15]$} \\
\hline & C. butryricum VPI 3266 & & $0.65 \mathrm{~mol} / \mathrm{mol}$ & $10.3 \mathrm{~g} / \mathrm{L} / \mathrm{h}$ & {$[54]$} \\
\hline & Engineered C.acetobutylicum & & $0.66 \mathrm{~mol} / \mathrm{mol}$ & $3 \mathrm{~g} / \mathrm{L} / \mathrm{h}$ & {$[55]$} \\
\hline & C. butyricum (DL07) & & $94.2 \mathrm{~g} / \mathrm{L}$ & $3.04 \mathrm{~g} /(\mathrm{L} \mathrm{h})$ & {$[56]$} \\
\hline \multirow[t]{3}{*}{ Enterobacter } & $\begin{array}{l}\text { Enterobacter aerogenes TISTR } \\
1468\end{array}$ & Ethanol & $0.59 \mathrm{~mol} / \mathrm{mol}$ & - & {$[57]$} \\
\hline & Enterobacter MT491125 & $\begin{array}{l}\text { 1,3 propanediol \& } \\
\text { 2,3-butanediol }\end{array}$ & $0.70 \mathrm{~g} / \mathrm{ml} \& 0.88 \mathrm{~g} / \mathrm{ml}$ & - & {$[58]$} \\
\hline & Enterobacter sp. LU1 & Succinic acid & $\begin{array}{l}0.38 \pm 0.21 \mathrm{~mol} / \mathrm{mol} \text { (Micro- } \\
\text { aerobic) } \\
0.58 \pm 0.11 \mathrm{~mol} / \mathrm{mol} \text { (Anaero- } \\
\text { bic) }\end{array}$ & $\begin{array}{l}0.19 \pm 0.09 \mathrm{~g} / \mathrm{L} / \mathrm{h} \\
0.24 \pm 0.12 \\
\mathrm{~g} / \mathrm{L} / \mathrm{h}\end{array}$ & [59] \\
\hline \multirow[t]{6}{*}{ E. coli } & Engineered E. coli $\mathrm{Sy} 03$ & Ethanol & $1 \mathrm{~mol} / \mathrm{mol}$ & $0.051 \mathrm{~g} / \mathrm{L} / \mathrm{h}$ & {$[60]$} \\
\hline & E. coli AC521 & Lactic acid & $0.9 \mathrm{~mol} / \mathrm{mol}$ & $0.97 \mathrm{~g} / \mathrm{L} / \mathrm{h}$ & {$[61]$} \\
\hline & Engineered $E$. coli & Succinate & $0.8 \mathrm{~mol} / \mathrm{mol}$ & - & {$[62]$} \\
\hline & Engineered $E$. coli & Succinate & $0.93 \mathrm{~mol} / \mathrm{mol}$ & - & {$[63]$} \\
\hline & E. coli YY-GS011 & Succinate & $0.92 \mathrm{~mol} / \mathrm{mol}$ & - & {$[64]$} \\
\hline & Engineered Escherichia coli & butanol & $6.9 \mathrm{~g} / \mathrm{L}$ & $0.18 \mathrm{~g} / \mathrm{L} / \mathrm{h}$ & {$[65]$} \\
\hline \multirow[t]{5}{*}{ Klebsiella } & Engineered $K$. pneumonia & Ethanol & $0.89 \mathrm{~mol} / \mathrm{mol}$ & $1.2 \mathrm{~g} / \mathrm{L} / \mathrm{h}$ & {$[66]$} \\
\hline & K. pneumonia encapsulated & 1,3 propanediol & $\begin{array}{l}0.65 \mathrm{~mol} / \mathrm{mol} \text { batch } \\
0.43 \mathrm{~mol} / \mathrm{mol} \text { continuous }\end{array}$ & $4.46 \mathrm{~g} / \mathrm{L} / \mathrm{h}$ & {$[67]$} \\
\hline & $K$. oxytoca lactate deficient & & $0.41-0.53 \mathrm{~mol} / \mathrm{mol}$ & $\begin{array}{l}0.63-0.83 \\
\mathrm{~g} / \mathrm{L} / \mathrm{h}\end{array}$ & {$[68,69]$} \\
\hline & K. pneumonia inactivated ADH & & $0.70 \mathrm{~mol} / \mathrm{mol}$ & $1.07 \mathrm{~g} / \mathrm{L} / \mathrm{h}$ & {$[70]$} \\
\hline & K. pneumoniae DSMZ 2026 & 1,3-propanediol & $0.42 \mathrm{~g} / \mathrm{g}$ & $1.57 \mathrm{~g} / \mathrm{L} / \mathrm{h}$ & [71] \\
\hline Lactobacillus & Lactobacillus reuteri $\mathrm{CH} 53$ & 1,3-propanediol & $68.32 \pm 0.84 \mathrm{~g} / \mathrm{L}$ & $\begin{array}{l}1.27 \pm 0.02 \\
\mathrm{~g} / \mathrm{L} / \mathrm{h}\end{array}$ & {$[72]$} \\
\hline Propionibacterium & Engineered $P$. acidipropionici & Propionic acid & $0.88 \mathrm{~mol} / \mathrm{mol}$ & $0.085 \mathrm{~g} / \mathrm{L} / \mathrm{h}$ & {$[73]$} \\
\hline \multirow[t]{2}{*}{ Mixed culture } & R. palustris CGA009 & Hydrogen & $6 \mathrm{~mol} / \mathrm{mol}$ & - & [74] \\
\hline & P. macerans & Hydrogen & $0.801 \mathrm{~mol} / \mathrm{mol}$ & & {$[75]$} \\
\hline \multirow[t]{3}{*}{ Fungi } & L. edodes & $\begin{array}{l}\text { Single cell oil } \\
\text { Oxalic acid }\end{array}$ & $0.1 \mathrm{~g} / \mathrm{g}$ & & [76] \\
\hline & A. niger & Single cell oil & $0.411 \mathrm{~g} / \mathrm{g}$ & - & [77] \\
\hline & Thamnidium elegans & Single cell oil (SCO) & - & - & [78] \\
\hline \multirow[t]{5}{*}{ Yeast } & Engineered $S$. cerevisiae & Ethanol & - & - & [79] \\
\hline & Y. lipolytica wrastislavia AWG7 & Citric acid & $0.33 \mathrm{~mol} / \mathrm{mol}$ & $1.16 \mathrm{~g} / \mathrm{L} / \mathrm{h}$ & {$[80]$} \\
\hline & Yarrowia lipolytica & Succinic acid & $0.45 \mathrm{~mol} / \mathrm{mol}$ & $1.45 \mathrm{~g} / \mathrm{L} / \mathrm{h}$ & [81] \\
\hline & Crytococus curvatus & Single cell oil & $52 \%$ lipid & - & {$[82]$} \\
\hline & Rhodotorula glutinis & & $36.5 \%$ lipid & - & [83] \\
\hline Microalgae & S. limacinum SR21 & DHA & - & $0.52 \mathrm{~g} / \mathrm{L} / \mathrm{h}$ & [84] \\
\hline
\end{tabular}

development [39] is shown in Fig. 7. In the aerobic route with the presence of oxygen, glycerol is converted to G3P (glycerol-3-phosphate) with a glycerol kinase. In the next process, DHAP (dihydroxyacetone phosphate) undergoes oxidation to create one mole of NADH through an $\mathrm{NAD}^{+}$ based G3P dehydrogenase [40].

Glycerol oxidation to dihydroxyacetone (DHA) producing a single mole of NADH is the first stage of microaerophilic 
Fig. 7 Microbial conversion of glycerol

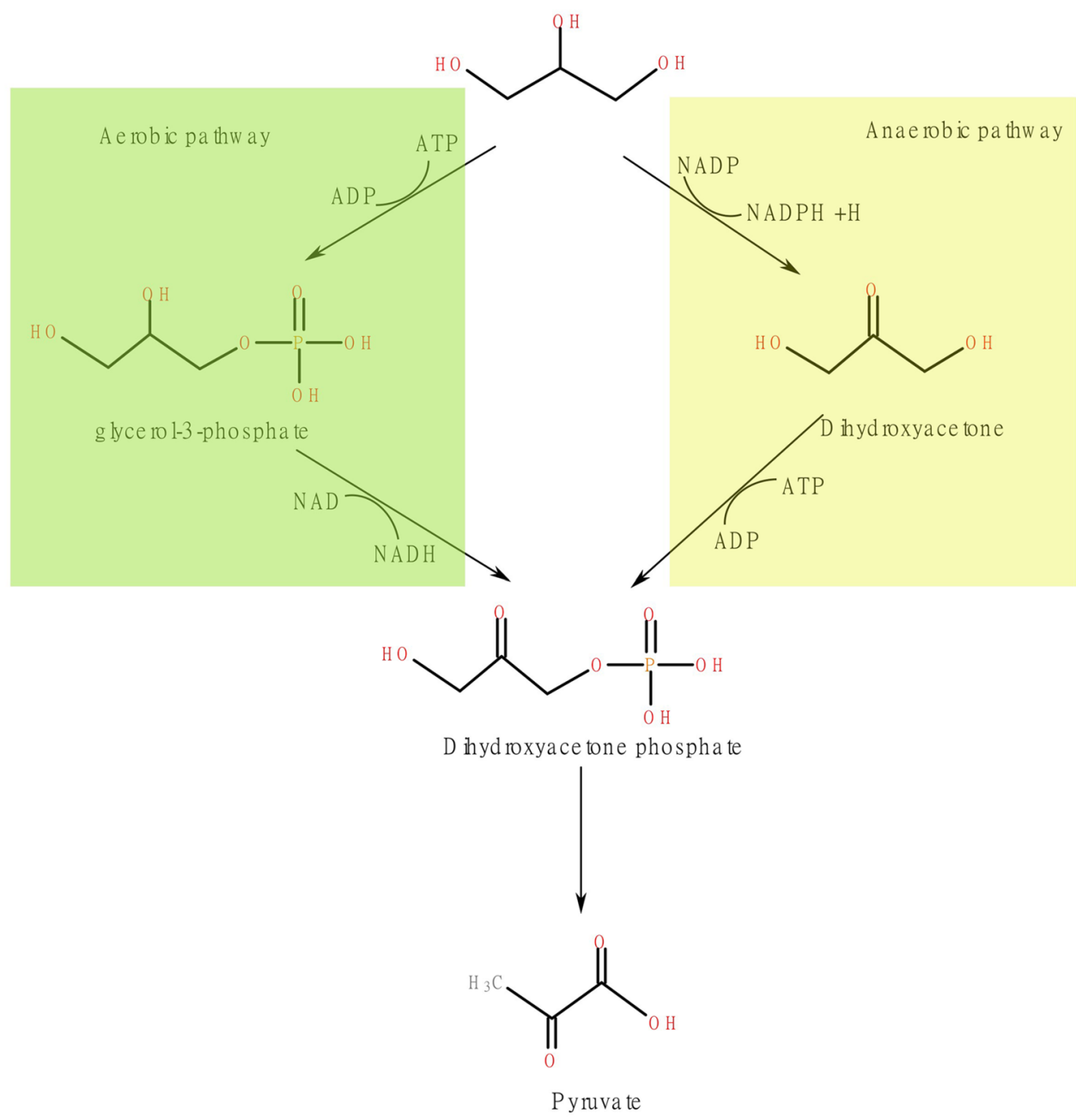

or anaerobic conditions, tailed from dihydroxyacetone to dihydroxyacetone phosphate using dihydroxyacetone kinase.

Glycerol oxidation is paired with a reductive pathway under low oxygen conditions via glycerol as a concluding electron receiver. These paths are coded in a single regulon called DHA regulon (dihydroxyacetone regulon). In particular, glycerol converted to 1,3-propanediol, the electrons from oxidation then transferred to reduction as NADH [41].

The route of reduction includes an enzymatic activity. The initial process is glycerol dehydration with a glycerol dehydratase to form hydroxy propionaldehyde (3-HPA). The next step is to reduce 3-HPA to 1,3-PDO with 1,3 propanediol oxidoreductase. Dehydratase glycerol is a complicated enzyme divided into two subcategories depending on the enzyme reactivation [42].

Adenosyl radical is the fundamental catalytic principle in both subcategories. The most important thing to prevent an unwanted reaction in which the radical is lost in the enzyme activity. Both subclasses vary with the radical adenosyl created. The initial category of glycerol dehydrates employs reactivation; vitamin $\mathrm{B} 12$ relies on the process. The enzyme is arranged like a heterotrimer dimer and genes for the complex reactivation with dehydrated glycerol in the DHA operon [43].

The three GldA, GldB, and GldC genes encrypt the individual subunits of the enzyme, and two additional GrdA and GrdB genes encode the factor for reactivation. This subclass is tolerant to oxygen. The enzyme inactivated by an excess of glycerol includes in the community of species Lactobacillus, Clostridium, Klebsiella, and Citrobacter [44].

The second subgroup of glycerol dehydrates utilises an independent re/activation mechanism of vitamin B12. They consist of two subunits that create a homo-dimer. Both proteins are encoded again in the DHA operon with genes (DhaB1 and DhaB2). This group of glycerol dehydrates oxygen-sensitive and glycerol-inactivated suicidally [45]. Until now, only a single strain was shown to have glycerol dehydrates. However, genome analyses for another microorganism that ferments glycerol showed that independent glycerol dehydratase contains vitamin B12 like $C$. difficile, C. botulinum, and other Clostridium species [44]. 
The sequence review of knowledgeable glycerol dehydratases based on vitamin B12 showed that both groups of glycerols were not homogeneous and formed from separate predecessors. Interestingly, some species also comprise all subclasses of glycerol dehydratases [46].

Another study of 2000 prokaryotic genomes has shown a very unusual distribution of DHA regulon. Around 111 of the prokaryotic genomes have a minor portion of the DHA regulon and various taxonomic phylae. For instance, actinobacteria, firmicutes (Clostridia, Lactobacillis), or Proteobacteria). Only the whole DHA regulon, such as Klebsiella spp was present in a few bacterial genomes [47]. The genomic study also indicates that gene distribution appears to be unequal for the oxidative and reductive branches. The reduction pathway genes are present in a more significant number of microbes, while the oxidation pathway gene distribution has been more restricted [48].

Yarrowia lipolytica is a micro-organism that channels glycerol into central carbon metabolism by an aerobic route through glycerol's phosphorylation, followed by oxidation into dihydroxyacetone phosphate shown in Fig. 3. Many yeasts exhibit an aerobic pathway to catabolise glycerol. Other carbon and electron flows are affected by eco-friendly considerations (nutrient restriction, $\mathrm{pH}$, temperature, dissolved oxygen) but also by strain sources and their sources of isolation [49].

\section{Glycerol into value-added products}

In the last decades, many researchers and industrialists found the valuable conversion of crude glycerol through chemical routes shown by publications and a patent filed in many countries. Industrialists create a supply chain by the purification process of the glycerol, originally from a residue of the biodiesel. However, many manufacturers converted into valuable products from these raw materials and gaining high value in different sectors. The crude glycerol is converted into value-added products like propionic acid, single cell oil, citric acid, ethanol, polyunsaturated fatty acid (DHA, EPA), biopolymers like PHA, and PHB with applications are described below [85].

\section{Ethanol}

Ethanol is one of the most significant organic substances used in consumer and industrial products. The primary industrial uses of this aliphatic alcohol are intermediate in other chemicals and solvent production [86]. In medicines, plastics, lacquers, polishers, plasticisers, and cosmetics, ethanol is used [87]. Ethanol is a topical anti-infective in medicine and an antidote for ethylene glycol or overdose of methanol. Ethanol-containing commercial products include drinks, fragrances, aftershaves and colognes, medicinal products, mouth washing, liniments, and some rubbing alcohols. It is the prominent alcohol formed in the fermentation process. It is used as a solvent, aerosols, paints, detergents, and thermometers [88].

Ethanol plays a vital role in fuel application due to its clean-burning features and lowers greenhouse gas emissions, primarily carbon dioxide [89]. Also, the crude agro-industrial residues are used as raw materials for alcoholic fermentation and an alternative substrate to solve the disposal issue [90]. However, ethanol with high solubility with water, biodegradability, and low toxicity. Ethanol as fuel is used as a blend with gasoline with 5-85\%. E85 is the most standard blend with $85 \%$ bioethanol and $15 \%$ gasoline. The other blends like E20 possess 20\% bioethanol and $80 \%$ gasoline, E10 contains $10 \%$ bioethanol and $90 \%$ gasoline commonly known as gasohol in the USA [91]. Whereas in Brazil, gasohol is the mixture with $24 \%$ of bioethanol and $76 \%$ gasoline. The higher concentrations of bioethanol are used in flexible fuel vehicles (FFV) that can function with the mixtures up to $85 \%$ bioethanol [92]. Bioethanol is converted into ethyl tertiary butyl ether that can be used as a $15 \%$ blend with gasoline [93]. The potential bioethanol production is an important bioprocess in the industrial sector.

Ethanol blends are influenced by various factors like climate, geographic location, and government policies. In general, about $10 \%$ anhydrous ethanol applicable in conventional combustion engines, while blends to $100 \%$ utilised in Flexi-fuel engines. Apart from using the spark-ignition engine, ethanol is also used in diesel engines as a transportation fuel because of its enhanced efficiency with nearzero particulate emission. The ED95 fuel comprises 95\% $\mathrm{v} / \mathrm{v}$ ethanol used in diesel engines in buses and trucks with $43 \%$ efficiency. Ethanol utilised in vehicles with fuel cells to evade pollution from combustion and eradicate the risk accompanied by hydrogen storage by lowering greenhouse gas emissions [94]. Ethanol is a well-known solvent in the industry. It is a colourless and flammable oxygenated hydrocarbon. Synthesis of ethanol from glycerol through chemical method is available, but the biological method by fermentation is the standard process.

Bioethanol is one of the fermentation products generated by anaerobic fermentation from glycerol [95]. The productivity of ethanol in the soil of a bacterium tested as a member of the Bacillus genus with 7.0-9.6 g/L ethanol production from the enriched glycerol-algal mixture. Jervis et al. found that Klebsiella planticola derived from the rumen was the main product of glycerol fermentation [96]. Due to its quality and the potential of reducing particulate emissions, bioethanol is considered an alternative to biofuels. At present, the bulk of bioethanol production originates from crops such as maize, sugarcane, wheat, and soy [97]. The unwanted effects on food production, including food 
price rises, a lack of feed, and growing land competition. Therefore, the use of biomass or glycerol waste to produce bioethanol has a substantial potential to ease these unwanted effects on food production [98].

Glycerol is used as the route for bioethanol by transforming into ethanol and hydrogen, and other chemical products. The conversion of ethanol depends on the glycerol concentration. Enterobacter aerogenes HU-101, Klebsiella sp. HE1 and Escherichia coli obtained a maximum yield of $0.6-1 \mathrm{~mol}$ ethanol $/ \mathrm{mol}$ glycerol at a $10 \mathrm{~g} / \mathrm{L}$ glycerol concentration [99]. The ethanol production from crude glycerol using microorganisms is shown in Table 3.

The Kluyvera cryocrescens S26 converts the crude glycerol to $27 \mathrm{~g} / \mathrm{L}$ bioethanol ( $80 \%$ yield) with $0.61 \mathrm{~g} / \mathrm{L} / \mathrm{h}$ productivity under microaerobic conditions [100]. A staged batch process achieved $28.1 \mathrm{~g} / \mathrm{L}$ by Pachysolen tannophilus (CBS4044) using crude glycerol as substrate [101]. Ethanol production improved using K. pneumoniae (GEM167) with a maximum output level of $21.5 \mathrm{~g} / \mathrm{L}$ and productivity of $0.93 \mathrm{~g} / \mathrm{L} / \mathrm{h}$ [102]. Glycerol of $34.5 \mathrm{~g} / \mathrm{L}$ and organic nitrogen at $6.42 \mathrm{~g} / \mathrm{L}$ produced $1.00 \mathrm{~mol} / \mathrm{mol}$ of ethanol using E. coli SS1. Most of the confirmed ethanol fermentation with glycerol as a substrate carried out using a serum bottle and $500 \mathrm{~mL}$ bottles at the laboratory level was described by Adnan et al. [103]. There is a window of opportunity for ethanol fermentation by Very high gravity (VHG) that saves energy for ethanol distillation. Because this technology produces high ethanol at lower cost and low waste, it could be more efficient in the industry. Still, ethanol production for Industrial-scale is challenging for the researcher that makes it possible from laboratory to industrial scale with low cost and high yield. [104].

1,3 propanediol: This three-diol carbon is a colourless viscous fluid used to manufacture polymers including poly trimethylene terephthalate (PTT). Aliphatic polyester, co-polyesters, adhesives, composites, layers, mouldings, laminates, wood lacquers, and anti-freeze products are commonly used. This compound has many significant uses for medicines, polymers, cosmetics, foodstuffs, adhesives, lubricants, solvents, and other products [14]. Enterobacter sp. MU-01 produced $0.70 \mathrm{~g} / \mathrm{L}$ of 1,3-propanediol and $0.88 \mathrm{~g} / \mathrm{L}$ of 2,3-butanediol at $10 \mathrm{~g} / \mathrm{L}$ crude glycerol [58]. The co-fermentation of glycerol and glucose using C. beijerinckii CCIC 22,954 produced $23.3 \mathrm{~g} / \mathrm{L}$ of 1,3-propanediol [105]. K. pneumoniae strain DSMZ 2026 successfully metabolised pure glycerol and biosynthesized 1.3-PD with $0.42 \mathrm{~g} / \mathrm{g}$ yield and $1.57 \mathrm{~g} / \mathrm{L} / \mathrm{h}$ productivity after $12 \mathrm{~h}$ of cultivation. Unfiltered crude glycerol fraction had an important impact on the production of $1,3-\mathrm{PD}(0.21 \mathrm{~g} / \mathrm{g}$ yield, $0.81 \mathrm{~g} / \mathrm{L} / \mathrm{h}$ productivity) [71].

\section{Hydrogen}

Hydrogen, the only byproduct fuel that produces water, is considered a potential environmentally friendly fuel. Crude glycerol is used as the substrate in microbial fermentation to produce hydrogen. The wide range of usable substrates in fermenting hydrogen allows the energy use of biomass for hydrogen to be combined with waste materials simultaneously. Microbial fermentation produced hydrogen is an appropriate alternative since hydrogen fuel only produces water as a byproduct that dramatically reduces $\mathrm{CO}_{2}, \mathrm{NO}_{x}$, particulate matter, and other pollutants, typically followed by fossil fuels [112]. Increased concentrations of crude glycerol co-digested with sanitary sewage by anaerobic consortium bacteria in anaerobic batch reactors at $30{ }^{\circ} \mathrm{C}$ and initial $\mathrm{pH} 7.0$ produced biohydrogen. The higher $\mathrm{H}_{2}$ generation of $35.82 \mathrm{mmol} \mathrm{L}^{-1}$ was observed by $63.9 \%$
Table 3 Ethanol production from glycerol/crude glycerol from micro-organisms

\begin{tabular}{lllll}
\hline Sno & Micro-organism & Yield or productivity & Substrate & References \\
\hline 1 & K. cryocrescens strain & $0.40 \mathrm{~g} / \mathrm{g}$ and $0.61 \mathrm{~g} / \mathrm{L} / \mathrm{h}$ & Crude glycerol & {$[100]$} \\
2 & P. tannophilus CBS4044 & $0.06 \mathrm{~g} / \mathrm{L} / \mathrm{h}$ & $\mathrm{CG}$ & {$[101]$} \\
3 & K. oxytocaFMCC-197 & $25.2 \mathrm{~g} / \mathrm{L}$ & $\mathrm{CG}$ & {$[106]$} \\
4 & Enterobacter aerogenes & $0.83 \mathrm{~g} / \mathrm{L} / \mathrm{h}$ & $\mathrm{CG}$ & {$[102]$} \\
& Hu-101 & & & \\
5 & Pachysolen tannophillus CBS4044 & $0.06 \mathrm{~g} / \mathrm{L} / \mathrm{h}$ & $\mathrm{CG}$ & {$[107]$} \\
6 & Enterobacter aerogenes & $0.5 \mathrm{~g} / \mathrm{L} / \mathrm{h}$ & $\mathrm{Glycerol}$ & {$[38]$} \\
& Hu-101 & $21.5 \mathrm{~g} / \mathrm{L}$ of EtOH in fed- & $\mathrm{CG}$ & {$[102]$} \\
7 & K. pneumoniae GEM167 & batch bioreactor & & {$[108]$} \\
& & $19.5 \mathrm{~g} / \mathrm{L}$ and & $\mathrm{CG}$ & {$[109]$} \\
& Klebsiella oxytoca M5al & productivity $0.56 \mathrm{~g} / \mathrm{L} / \mathrm{h}$ & & {$[110]$} \\
9 & Enterobacter aerogenes ATCC 29,007 & $5.38 \mathrm{~g} / \mathrm{L}$ & $\mathrm{CG}$ & {$[108]$} \\
10 & E. coli ATCC 11,505 immobilsed & $96.7 \mathrm{~g} / \mathrm{L}$ & $\mathrm{CG}$ & {$[111]$} \\
11 & Escherichia coli EH05 & $20.7 \mathrm{~g} / \mathrm{L}$ of ethanol & $\mathrm{CG}$ \\
12 & E. aerogenes & $204 \mathrm{mM}$ of ethanol & $\mathrm{CG}$ & \\
\hline
\end{tabular}


consumption of crude glycerol [113]. Microbial immobilisation has enhanced cumulative hydrogen production (CHP) and hydrogen yield (HY). PVA-alginate is used to immobilise microbes. In the case of immobilisation microorganisms, the highest CHP and HY were $64 \mathrm{~mL} / 100 \mathrm{~mL}$ and glycerol was $0.52 \mathrm{~mol} \mathrm{H}_{2} / \mathrm{mol}$ glycerol than suspended microorganisms with glycerol $9 \mathrm{~mL} / 100 \mathrm{~mL}$ and glycerol $0.29 \mathrm{~mol} \mathrm{H}_{2} /$ mol glycerol [114].

\section{Propanoic acid}

It is a universal preservative originating directly from a metabolic pathway analogous to the succinic acid pathway. Propanoic acid is increasingly used to develop a biotechnological production method for solvents, pesticides, artificial flavors, heat plastics, and pharmaceuticals through its various industrial applications. The main strains employed to convert glycerol to propionate are $C$. acnes, $C$. propionicum and. P. acidipropionici [115]. Propionic acid is produced from crude glycerol in an anaerobic fluidized bed reactor. The reactor is operated with hydraulic retention times varying from 8 to $0.5 \mathrm{~h}$ under mesophilic conditions. The maximum yield of $0.48 \pm 0.06 \mathrm{~g}$ propionic acid $\mathrm{g} \mathrm{COD}^{-1}$ with $4.09 \pm 1.29 \mathrm{~g} / \mathrm{L} / \mathrm{h}$ productivity was noticed [116]. The propionic acid production's metabolic reaction is a cyclic reaction dependent upon pyruvate and NADH equivalents. The exogenous $\mathrm{CO}_{2}$ supply varied from 1.56 to $2.94 \mathrm{~g} / \mathrm{L} /$ day propionic acid production. Enhanced metabolism of glycerol and increased volume productivity were found when $\mathrm{CO}_{2}$ was delivered to the dissimilation glycerol process [117]. Using Propionibacterium freudenreichii subsp. shermanii, over-expressing native propionyl-CoA: succinate CoA Transferase (CoAT) has been examined on glucose, glycerin, and mixtures as a carbon source on propionic acid fermentation. The propionic acid production with $10 \%$ yield and $46 \%$ productivity is shown with the mutant. Metabolic flux analysis has shown that CoAT overexpression has diverted more carbon fluxes to propionic acid, resulting in higher propionic acid with purity and preference for glycerol over glucose [118]. Propionic acid production using waste substrates like glycerol is promising and cost-effective than other sugars [119].

\section{Single-cell oil}

In industrial applications, single-cell oil or SCO has been identified in microbial lipids that can replace triacylglycerol plants. Fed-batch systems seem to allow lipid and cell density to be increased. S. limacinum SR21, a marine microalgae found to grow faster in crude glycerol and accumulate high lipid levels. In the case of batch cultivation using crude glycerol, cell growth was substantially inhibited at crude glycerol levels of up to $35 \mathrm{~g} / \mathrm{L}$ due to the inhibition of substrate and the presence of methanol. The optimal substrate concentration of the processed crude glycerol was increased to $35 \mathrm{~g} / \mathrm{L}$ with high lipid content of $73.3 \%$ (w/w) [120]. Fed-batch operations generally have obtained greater lipid than batch operations because the substrate inhibition is effectively alleviated $[80,121]$. Further improvement was made by using a two-stage fed-batch operation. A study of 12 days Cryptococcus curvatus with crude glycerol derived from yellow grease. The two-stage fed-batch strategy achieved a greater cell density of $32.9 \mathrm{~g} / \mathrm{L}$ and lipid content of $52 \% \mathrm{w} / \mathrm{w}$ compared to the one-stage fed-batch operation of $31.2 \mathrm{~g} / \mathrm{L}$ cell density and $44.2 \%$ lipid content $\mathrm{w} / \mathrm{w}$ [80].

\section{Butanol}

The development of biobutanol is particularly important because it has better physical characteristics as an alternative fuel. It is applied in plastics, polymers, lubricants, and brake fluid. It can be used as a fuel source. As an eco-friendly and effective solvent for product cleaning and polishing. $\mathrm{N}$-butanol is present in many drinks and foods in the USA and is used as a food artificial aroma. Used in the cosmetics sector, shampoos, shaving products, and soaps. As a chemical intermediate, other essential compounds like glycol ether, acrylate esters, amino resins, acetates, and amines will be generated. The promising $n$-butanol producer Clostridium acetobutylicum KF158795 was stated to use glycerol for substrate and to produce $13.57 \mathrm{~g} / \mathrm{L}$ of butanol in $96 \mathrm{~h}$ under optimised conditions [122]. Butanol production of $16.6 \mathrm{~g} / \mathrm{L}$ was achieved with a yield of $0.43 \mathrm{~g} / \mathrm{g}$ by glycerol using clostridium sp. strain CT7. The same species used directly to convert crude glycerol to $11.8 \mathrm{~g} / \mathrm{L}$ butanol without primary treatment [53]. Butanol production from glycerol was studied in polyvinyl alcohol particles entrapped by Clostridium pasteurianum. The glycerol of different impurities from biodiesel production achieved butanol productivity of $2.90 \mathrm{~g} / \mathrm{L} / \mathrm{h}$ and $1.76 \mathrm{~g} / \mathrm{L} / \mathrm{h}$ [123].Clostridium sp. strain CT 7 produced $41.9 \mathrm{~g} / \mathrm{L}$ of butanol and $0.4 \mathrm{~g} / \mathrm{L}$ of ethanol from $103.3 \mathrm{~g} / \mathrm{L}$ of glycerol with pervaporation [124].

\section{Glyceric acid}

Glyceric acid is also known as hydroxyacetic acid. Glycolic acid is used in the garment industry for dyeing, and tanning agents in food manufacturing, a flavoring agent, a preservative, and an agent for skincare in pharmaceutical manufacturing. It is also used in plastic and adhesives. In emulsion polymers, solvents, and additives, glycolic acid is often used to enhance flow properties and provide gloss. Gluconobacter sp. NBRC3259 was used to produce glyceric acid from crude glycerol using activated charcoal pre-treatment. Glyceric acid of $49.5 \mathrm{~g} / \mathrm{L}$ and dihydroxyacetone of $28.2 \mathrm{~g} / \mathrm{L}$ was produced from $174 \mathrm{~g} / \mathrm{L}$ of glycerol [125]. 


\section{Citric acid}

Citric acid is used as an emulsifier in ice creams, as a purifier in the pharmaceutical sector, in cosmetics, and so forth. Citric acid is an acidulant, buffering agent, emulsifier, flavorant, preservative, and sequestrant commonly used in many industries in food, beverages, pharma, nutrient, and cosmetic products. The first notable new use as a joint producer with zeolites, primarily in concentrated fluid detergents, is household detergents and dishwashing cleaners. The citric acid serves as a builder, chelating the water hardness of $\mathrm{Ca}^{2+}$ and $\mathrm{Mg}^{2+}$ ions, but does not contribute to eutrophication of aquatic systems, as opposed to phosphate builders. The glycerol sources from three biodiesel industry ROTHSAY, BIOLIQ, and BIOCARDEL was used to produce citric acid of $18.70 \mathrm{~g} / \mathrm{L}, 12.0 \mathrm{~g} / \mathrm{L}$, and $8.30 \mathrm{~g} / \mathrm{L}$ respectively at $96 \mathrm{~h}$ using Yarrowia lipolytica SKY7 [126]. Y. lipolytica strain Gut 1 and Gut2 using crude glycerol as substrate produced $42.5 \pm 2.4 \mathrm{~g} / \mathrm{L}$ isocitric acids [127].

\section{Polyunsaturated fatty acids}

DHA (docosahexaenoic acid), as well as EPA (eicosapentaenoic acid) both, are significant omega-3 PUFA because of their critical function in cancer therapy, cardiovascular disease, and Alzheimer's. Most of the PUFAs are fish that are less favored because they accumulate undesirable odors and harmful contaminants [128]. EPA and DHA are known for their engagement in exercise performance to enhance fatigue recovery and stamina as well as preserve immune function. Also, exhaustive, or unusual exercise induces muscle tiredness and retarded onset of muscle soreness (DOMS). Oxidative stress and inflammatory reactions occur simultaneously [129].

DHA foods are helpful because DHA is important for brain functioning. The use of abundant DHA in the diet enhances brain growth and learning skills. It is good for the eyes and helps to heal from such vision problems. DHA was reported for the prevention of and treatment of senile dementia, hypertension, asthma, depression, diabetes mellitus, myocardial infarction, thrombosis, cardiac disease, and certain types of cancer DHA has a positive impact [130]. Production of DHA with $17.25 \pm 0.33 \mathrm{~g} / \mathrm{dm}^{3}$ by Schizochytrium sp. grown on waste glycerol as organic carbon source on glycerol waste [131]. The mixed substrate of glucose and glycerol by fed-batch fermentation with Thraustochytriidae sp. PKU\#Mn16 using produced DHA yield of $8.65 \%$ and productivity of $100.7 \pm 2.9 \mathrm{mg} / \mathrm{L} / \mathrm{h}$ [132].

EPA was derived from fungus Pythium irregular waste glycerol with a final concentration of $90 \mathrm{mg} / \mathrm{L}$ and productivity of $14.9 \mathrm{mg} / \mathrm{L} / \mathrm{day}$ [133]. The algal species Schizochytrium limacinum SR21 developed with a DHA productivity of $0.51 \mathrm{~g} / \mathrm{L} /$ day with waste glycerol [134].
Polymer compounds: Polymer compounds like acrolein, polyhydroxyalkanoates, polyhydroxy butyrates exhibits their significance. Acrolein is a significant chemical source for acrylic acid industries, that mostly used in paints, plastics, and adhesives. It is widely used for the manufacture of superabsorbent polymers and $n$-butyl acrylate. Acrolein can be derived as an oxidation result of glycerol dehydration [135]. Crude glycerol is converted to acrolein with $56 \%$ and $81.1 \%$ yield by supercritical process $\left(380{ }^{\circ} \mathrm{C} \&\right.$ $27.6 \mathrm{MPa})$ and subcritical water process $\left(335^{\circ} \mathrm{C} \& 20 \mathrm{MPa}\right)$ using sulphuric acid as catalyst [136]. Nonthermal Plasma Induced Fabrication of Solid Acid Catalysts like HSiW-Al and HSiW-Si have shown $98.9 \pm 1.8$ and $93.5 \pm 1.8$ conversion (mol \%) of glycerol dehydration to acrolein [137].

The glycerol oxidation reaction offers the ability to turn glycerol into value-added goods, boost the economy of biodiesel production and provide new alternative chemical sources for the industry. The produced acrylic acid and its esters exhibit characteristic features with clarity, simple adherence, and plasticity [138]. Sequential dehydration and oxidation of crude glycerol convert to $86 \%$ of acrylic acid [139].

The biopolymers were noticed with crude glycerol as a biodiesel byproduct of the small volume of nitrogen and phosphate. Many scientists documented the development of bio-polymers via crude glycerol as a substrate of carbon source through microbial fermentation [140].

Polyhydroxyalkanoates (PHAs) have characteristic features very similar to synthetic plastics. The special features that make them attractive biomedical materials are their biocompatibility biodegradability, and non-toxicity. PHAs suitable for many medical applications have been found for bio-control agents, drug carriers, biodegradable implants, tissue engineering, memory enhancers, and anticancer drugs [141]. The current PHA industry is affected by the high price of the carbon substrate. The use of low-value crude glycerol from the biodiesel industry could reduce the production cost and thus makes PHA more marketable. The crude glycerol has been proven as the potential lowcost feedstocks for PHA production. Polyhydroxyalkanoates (PHAs) reflect natural biopolymers formed by the fermentation of many microbial strains using glycerol via intracellular fermentation. The intracellular accumulation of 56\% PHA in Halomonas sp. SA8, the soil bacteria of Finnish soils and sediments identified by fermentation with crude glycerol by a mineral medium [142]. Bacillus thuringiensis EGU45 produces 1.5-3.5 g/L PHA using crude glycerol and nutrient broth [143]. The combination of crude glycerol and activated sludge with 3 hydroxybutyrate and hydroxy valerate produced $80 \mathrm{Wt} \%$ of PHA [144]. The waste glycerol from the biodiesel industry produced $5.63 \mathrm{~g} / \mathrm{L}$ with $64 \%$ PHA by Burkholderia cepacia BPT1213 [145]. PHA content of $48 \% \mathrm{CDW}$ in $48 \mathrm{~h}$ with a maximum PHA productivity 
of $13.16 \mathrm{mg} / \mathrm{L} / \mathrm{h}$ produced by Pseudomonas mosselii TO7 [146].

Polyhydroxy butyrate (PHB) is biodegradable and biocompatible and, in turn, defines its ecotoxicity and human toxicity in terms of the environment. Consequently, PHB has found useful applications for tissue engineering and related biomedicines such as surgical sutures, thermogels as a controlled release medication supply vehicle, surgical mesh, wound dressing and absorbable nerve guides, bone tissue, and nerve regeneration tissue scaffolding, cardiovascular and cartilage support. PHB is a powerful biomedical and packaging substitute. However, due to secondary crystallisation and slow nucleation speeds, numerous physical disadvantages, such as high production costs, heat instability, and poor mechanical properties restricted its competitiveness with conventional plastics in industrial and biomedical applications [147]. Transformation of glycerol up to $60 \%$ polyhydroxybutyrate with Bacillus megaterium was performed [148]. PHA production yield $0.44 \mathrm{~g} / \mathrm{g}$ with 59\% PHA content (CDW) using mixed microbial cultures and crude glycerol as feedstock [149] (see Fig. 7).

Water treatment: Various natural source wastes from chicken feathers, sheep wool, human hair, etc. are used for water processing $[150,151]$. Wastes from biodiesel industry i.e. unrefined glycerol used in a variety of other ways. Recently, Bodk et al. explored the use of biodiesel waste as a source of organic carbon for a municipal wastewater treatment plant's denitrification. The experiments were first devised in the laboratory and, after obtaining promising results, they were scaled up. The biodiesel waste is used in the denitrification phase as a result of the findings [152]. Fountakis et al. found that anaerobic digesters successful for the treatment of sewage sludge with the aid of unrefined glycerol to improve the biogas production if the concentration does not exceed 1\% (v/v) in the sludge [153].

Co-digestion and cogasification: Glycerol has also served as a biogas source in digesters that work with the aid of heat and a carbon source to be codigested raw material for anaerobic decomposition. The addition of glycerol to a biodigester degrading swine manure results in an increase in methane production according to Odorica et al. [154]. The biogas production crude glycerin, a by-extracted biodiesel ingredient, is an appropriate carbon source when added to cattle manure with $5 \%$ to $10 \%$ has helped increase rural biodigester output and improve the quality. Glycerol can also act as a substrate to aid in the production of hydrogen and methane from industrial and domestic wastewater. The possibility of using unrefined glycerol and hardwood chips up to $20 \%$ as feedstock in a fixed-bed downdraft gasifier to manufacture syngas, which is made up of $\mathrm{CO}, \mathrm{CO}_{2}, \mathrm{CH}_{4}$, $\mathrm{N}_{2}$, and $\mathrm{H}_{2}$ [33]. Biodiesel production revalorisation does possess several advantages including low nutrient requirements, enhanced efficiency, and the generation of methane, such as those mentioned by Silva [155].

\section{Animal feed}

Crude glycerol from the biodiesel industry for many years used as animal feed. As animal nutrition demands are anticipated to rise, a greater amount of glycerol is expected to be consumed by the animal. There has been considerable analysis of the possibility of using glycerol instead of corn grain in lactating cow diets. Biodiesel unrefined glycerol contains impurities. However, about $10 \%$ used as animal feed exhibited beneficial growth performance in pigs [156]. Similarly, the same level of crude glycerol as a diet supplement to catfish has no negative impact on weight, feed intake, feed conversion, and lipid utilisation.

\section{Other applications}

Glycerol is called an outstanding additive for improving concrete by cement performance with compression strength, facilitating stronger grinding and handling properties [157].
Fig. 8 Various applications of glycerol

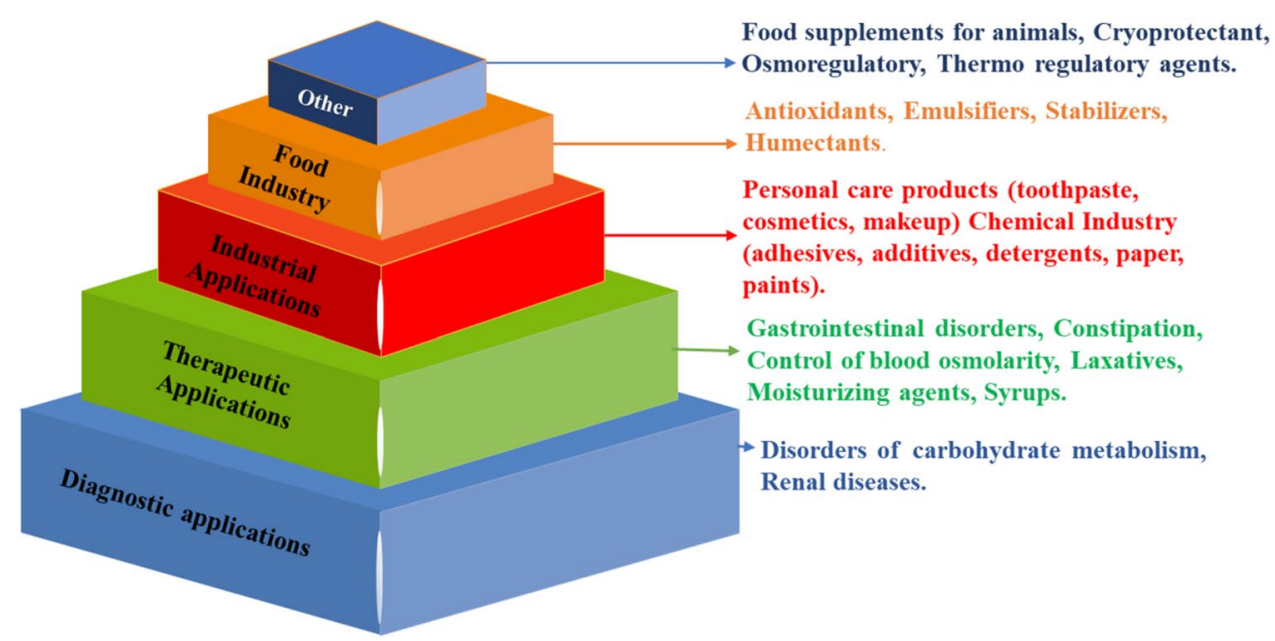


Additives may be used between 150 and 500 g per ton of cement. A more thorough investigation into glycerol application on cement clinkers revealed that glycerol can interfere with both the chemical and physical. The studies conducted have concluded that glycerol during the course of grinding alters the particles' surface tension [158].

\section{Future prospective}

The massive global production of glycerol by biodiesel industries challenges the researchers to develop new technology which can be commercially viable. It also assists in the valorisation of glycerol with the purpose of glycerol surplus that does not affect the biodiesel industry's sustainability, i.e., contributes to the biodiesel industry's environmental economics. This industry can also be profitable and contribute to the biorefinery. Microbial cell factories proposed the micro-organism by engineering depends on glycerol for developing several potential products. The market scenario of biofuels will change because of the creation of new technologies involving the production of ethanol. Rather than seeing crude glycerol as waste, biodiesel industries become aware as a potential material for other potential industries by the fermentation process, which plays a significant role in the current industries and leads to a new pathway for the biofuels sector. Researchers reported pre-treatment is a better way to utilisation crude glycerol for ethanol production, Therefore, further research is required, as collective removal methods for various kinds of impurities will lead to an industrial process that will be useful to produce ethanol soon. Apart from that Some researchers also carried out ethanol from crude glycerol without pre-treatment for saving cost. The use of crude glycerol in the formulation of value-added material shows that crude glycerol can be a critical part of the bio-refining industry. The government needs to develop a new regulation and protocol to deal with biodiesel industries for the utility of byproduct glycerol waste that leads to protect the environment.

Besides, genetically engineered microbial strains need to develop and boost the crude glycerol's ethanol output ability. However, many of the current technologies available but still require more advancement to make the integration into biorefineries cost-efficient and operationally feasible.

\section{Conclusion}

Biodiesel is the prominent fuel for the future as considering the environmental issue and reduce carbon footprint. The increase in biodiesel production has contributed to an increase in glycerol byproducts as waste. It is important to find alternative, safe technologies for the use of crude glycerol. The flexibility of glycerol allows being used in many industrial segments as a raw material for the manufacture of chemical intermediates or goods. The value-added chemicals formed from the crude glycerol utilised in cosmetics, pharmaceuticals, adhesives, detergents, paints, paper, and feed products. The bioconversion approach appears to be a feasible source for the development of the economy and environmental maintenance.

Acknowledgements The authors are grateful to Universiti Malaysia Pahang for providing financial support through higher education Malaysia's ministry under the fundamental research grant scheme number FRGS/1/2019/STG05/UMP/01/1 (UMP internal Reference no RDU1901123). The author also thankful to IPS for Doctoral research scheme (DRS).

\section{References}

1. Owusu PA, Asumadu-Sarkodie S. A review of renewable energy sources, sustainability issues and climate change mitigation. Dubey S, ed. Cogent Eng. 2016. https://doi.org/10.1080/23311 916.2016.1167990.

2. Abdul Malek ABM, Hasanuzzaman M, Rahim NA. Prospects, progress, challenges and policies for clean power generation from biomass resources. Clean Technol Environ Policy. 2020;22(6):1229-53. https://doi.org/10.1007/ s10098-020-01873-4.

3. Linda Capuano. International Energy Outlook 2020 (U.S. Energy Information Administration).; 2020. https://www.eia.gov/outlo oks/ieo/. Accessed 24 Apr 2021.

4. Zahan K, Kano M. Biodiesel production from palm oil, its byproducts, and mill effluent: a Review. Energies. 2018;11(8):2132. https://doi.org/10.3390/en11082132.

5. P Ravindra. Horizons in bioprocess engineering. Edited by $\mathrm{P}$ Ravindra. Horizons in Bioprocess Engineering. first. Springer International Publishing. 2019. https://doi.org/10.1007/ 978-3-030-29069-6.

6. Monteiro MR, Kugelmeier CL, Pinheiro RS, Batalha MO, da Silva CA. Glycerol from biodiesel production: technological paths for sustainability. Renew Sustain Energy Rev. 2018;88:109-22. https://doi.org/10.1016/j.rser.2018.02.019.

7. Alves IRFS, Mahler CF, Oliveira LB, Reis MM, Bassin JP. Assessing the use of crude glycerol from biodiesel production as an alternative to boost methane generation by anaerobic co-digestion of sewage sludge. Biomass Bioenerg. 2020;143:105831. https://doi.org/10.1016/j.biombioe.2020.105831.

8. Jindapon W, Ruengyoo S, Kuchonthara P, Ngamcharussrivichai $\mathrm{C}$, Vitidsant T. Continuous production of fatty acid methyl esters and high-purity glycerol over a dolomite-derived extrudate catalyst in a countercurrent-flow trickle-bed reactor. Renew Energy. 2020;157:626-36. https://doi.org/10.1016/j.renene.2020.05.066.

9. Yousuf A, Sannino F and Pirozzi D. Lignocellulosic biomass to liquid biofuels. Edited by Yousuf A. Lignocellulosic Biomass to Liquid Biofuels. Elsevier.2019. https://doi.org/10.1016/ C2017-0-03529-2.

10. Sharma A, Arya SK. microbial biofuel and their impact on environment and agriculture. Cham: Springer; 2020. p. 139-61. https://doi.org/10.1007/978-3-030-53933-7_8.

11. Lee M, Lin YL, Te CP, Den W. Environmental and energy assessment of biomass residues to biochar as fuel: a brief review with recommendations for future bioenergy systems. J Clean Prod. 2020;251:119714. https://doi.org/10.1016/j.jclepro.2019.119714. 
12. Chong CC, Aqsha A, Ayoub M, et al. A review over the role of catalysts for selective short-chain polyglycerol production from biodiesel derived waste glycerol. Environ Technol Innov. 2020;19:100859. https://doi.org/10.1016/j.eti.2020.100859.

13. Singh D, Sharma D, Soni SL, Sharma S, Kumar Sharma P, Jhalani A. A review on feedstocks, production processes, and yield for different generations of biodiesel. Fuel. 2019;2020(262):116553. https://doi.org/10.1016/j.fuel.2019. 116553.

14. Kosamia NM, Samavi M, Uprety BK, Rakshit SK. Valorization of biodiesel byproduct crude glycerol for the production of bioenergy and biochemicals. Catalysts. 2020;10(6):609. https:// doi.org/10.3390/catal10060609.

15. Carlucci C. A focus on the transformation processes for the valorization of glycerol derived from the production cycle of biofuels. Catalysts. 2021;11(2):280. https://doi.org/10.3390/ catal11020280.

16. Nomanbhay S, Ong MY, Chew KW, Show P-L, Lam MK, Chen W-H. Organic carbonate production utilizing crude glycerol derived as by-product of biodiesel production: a review. Energies. 2020;13(6):1483. https://doi.org/10.3390/en13061483.

17. Leoneti AB, Aragão-Leoneti V, de Oliveira SVWB. Glycerol as a by-product of biodiesel production in Brazil: alternatives for the use of unrefined glycerol. Renew Energy. 2012;45:138-45. https://doi.org/10.1016/j.renene.2012.02.032.

18. Fokum E, Zabed HM, Yun J, Zhang G, Qi X. Recent technological and strategical developments in the biomanufacturing of 1,3-propanediol from glycerol. Int J Environ Sci Technol. 2021. https://doi.org/10.1007/s13762-020-03036-w (Published online January 3, 2021:1-24).

19. Rezania S, Oryani B, Park J, et al. Review on transesterification of non-edible sources for biodiesel production with a focus on economic aspects, fuel properties and by-product applications. Energy Convers Manag. 2019;201:112155. https://doi.org/10. 1016/j.enconman.2019.112155.

20. Anuar MR, Abdullah AZ. Challenges in biodiesel industry with regards to feedstock, environmental, social and sustainability issues: a critical review. Renew Sustain Energy Rev. 2016;58:208-23. https://doi.org/10.1016/j.rser.2015.12.296.

21. Atadashi IM, Aroua MK, Abdul Aziz AR, Sulaiman NMN. The effects of catalysts in biodiesel production: a review. J Ind Eng Chem. 2013;19(1):14-26. https://doi.org/10.1016/j.jiec.2012. 07.009 .

22. Singh A, He B, Thompson J, Van Gerpen J. Process optimization of biodiesel production using alkaline catalysts. Appl Eng Agric. 2006;22(4):597-600. https://doi.org/10.13031/2013. 21213.

23. Chen J, Li J, Dong W, et al. The potential of microalgae in biodiesel production. Renew Sustain Energy Rev. 2016;2018(90):336-46. https://doi.org/10.1016/j.rser.2018.03. 073.

24. Röttig A, Wenning L, Bröker D, Steinbüchel A. Fatty acid alkyl esters: perspectives for production of alternative biofuels. Appl Microbiol Biotechnol. 2010;85(6):1713-33. https://doi.org/10. 1007/s00253-009-2383-z.

25. Rodrigues A, Bordado JC, Dos Santos RG. Upgrading the glycerol from biodiesel production as a source of energy carriers and chemicals - a technological review for three chemical pathways. Energies. 2017. https://doi.org/10.3390/en10111817.

26. Ciriminna R, Pina CD, Rossi M, Pagliaro M. Understanding the glycerol market. Eur J Lipid Sci Technol. 2014;116(10):1432-9. https://doi.org/10.1002/ejlt.201400229.

27. Okoye PU, Hameed BH. Review on recent progress in catalytic carboxylation and acetylation of glycerol as a byproduct of biodiesel production. Renew Sustain Energy Rev. 2016;53:558-74. https://doi.org/10.1016/j.rser.2015.08.064.
28. Ferrero F, Periolatto M. Glycerol in comparison with ethanol in alcohol-assisted dyeing. J Clean Prod. 2012;33:127-31. https:// doi.org/10.1016/j.jclepro.2012.04.018.

29. Elgharbawy AS, Sadik WA, Sadek OM, Kasaby MA. A review on biodiesel feedstocks and production technologies. J Chil Chem Soc. 2021;66(1):5098-109. https://doi.org/10.4067/ S0717-97072021000105098.

30. Khazayialiabad A, Iranshahi D. Inherent $\mathrm{CO} 2$ capture and $\mathrm{H} 2$ production enhancement in a new glycerol steam reformer coupled with chemical looping combustion. Energy Fuels. 2021. https://doi.org/10.1021/acs.energyfuels.0c02664 (Published online March 1, 2021:acs.energyfuels.0c02664).

31. Rahim SANM, Lee CS, Abnisa F, et al. A review of recent developments on kinetics parameters for glycerol electrochemical conversion - a by-product of biodiesel. Sci Total Environ. 2020;705:135137. https://doi.org/10.1016/j.scitotenv.2019. 135137.

32. Mamtani K, Shahbaz K, Farid MM. Glycerolysis of free fatty acids: a review. Renew Sustain Energy Rev. 2021. https://doi. org/10.1016/j.rser.2020.110501.

33. Yang F, Hanna MA, Sun R. Value-added uses for crude glycerol-a byproduct of biodiesel production. Biotechnol Biofuels. 2012;5(1):13. https://doi.org/10.1186/1754-6834-5-13.

34. Aroua MK, Cognet P. Editorial: from glycerol to value-added products. Front Chem. 2020;8:69. https://doi.org/10.3389/fchem. 2020.00069.

35. Samul D, Leja K, Grajek W. Impurities of crude glycerol and their effect on metabolite production. Ann Microbiol. 2014;64(3):891-8. https://doi.org/10.1007/s13213-013-0767-x.

36. Dasari M. Crude glycerol potential described. Feedstuffs. 2007:15;79(43):1-3.

37. Bharathiraja B, Selvakumari IAE, Jayamuthunagai J, et al. Biochemical conversion of biodiesel by-product into malic acid: a way towards sustainability. Sci Total Environ. 2020;709:136206. https://doi.org/10.1016/j.scitotenv.2019.136206.

38. Suhaimi SN, Phang LY, Maeda T, et al. Bioconversion of glycerol for bioethanol production using isolated Escherichia coli SS1. Brazilian J Microbiol. 2012;43(2):506-16. https://doi.org/10. 1590/S1517-83822012000200011.

39. Ko YS, Kim JW, Lee JA, et al. Tools and strategies of systems metabolic engineering for the development of microbial cell factories for chemical production. Chem Soc Rev. 2020;49(14):4615-36. https://doi.org/10.1039/d0cs00155d.

40. Liu JZ, Xu W, Chistoserdov A, Bajpai RK. Glycerol dehydratases: biochemical structures, catalytic mechanisms, and industrial applications in 1,3-propanediol production by naturally occurring and genetically engineered bacterial strains. Appl Biochem Biotechnol. 2016;179(6):1073-100. https://doi.org/10. 1007/s12010-016-2051-6.

41. Saxena RK, Anand P, Saran S, Isar J. Microbial production of 1,3-propanediol: Recent developments and emerging opportunities. Biotechnol Adv. 2009;27(6):895-913. https://doi.org/10. 1016/j.biotechadv.2009.07.003.

42. Przystałowska H, Zeyland J, Szymanowska-Powałowska D, Szalata M, Słomski R, Lipiński D. 1,3-Propanediol production by new recombinant Escherichia coli containing genes from pathogenic bacteria. Microbiol Res. 2015;171:1-7. https://doi. org/10.1016/j.micres.2014.12.007.

43. Testa B. Principles of Drug Metabolism. In Burger's Medicinal Chemistry and Drug Discovery, 403-454. Hoboken, NJ, USA: John Wiley \& Sons, Inc. 2010. https://doi.org/10.1002/04712 66949.bmc033.pub2

44. Russmayer H, Egermeier M, Kalemasi D, Sauer M. Spotlight on biodiversity of microbial cell factories for glycerol conversion. Biotechnol Adv. 2019;37(6):107395. https://doi.org/10.1016/j. biotechadv.2019.05.001. 
45. Cusack S. Sequence, structure and evolutionary relationships between class 2 aminoacyl-tRNA synthetases: An update. Biochimie. 1993;75(12):1077-81. https://doi.org/10.1016/03009084(93)90006-E.

46. Martens JH, Barg H, Warren M, Jahn D. Microbial production of vitamin B12. Appl Microbiol Biotechnol. 2002;58(3):27585. https://doi.org/10.1007/s00253-001-0902-7.

47. Zhang Z, Wang J, Wang J, Wang J, Li Y. Estimate of the sequenced proportion of the global prokaryotic genome. Microbiome. 2020;8(1):134. https://doi.org/10.1186/ s40168-020-00903-z.

48. Karlin S, Mrazek J. Predicted highly expressed genes of diverse prokaryotic genomes. J Bacteriol. 2000;182(18):5238-50. https://doi.org/10.1128/JB.182.18.5238-5250.2000.

49. Kumar A. Climate Change: Challenges to Reduce Global Warming and Role of Biofuels. In Climate Change, Photosynthesis and Advanced Biofuels, 2020; 13-54. Springer Singapore. https://doi.org/10.1007/978-981-15-5228-1_2.

50. Maervoet VET, Beauprez J, De Maeseneire SL, Soetaert WK, De Mey M. Citrobacter werkmanii, a new candidate for the production of 1,3-propanediol: Strain selection and carbon source optimization. Green Chem. 2012;14(8):2168-78. https://doi.org/10.1039/c2gc35369e.

51. Yang C, Jiang P, Xiao S, Zhang C, Lou K, Xing XH. Fedbatch fermentation of recombinant Citrobacter freundii with expression of a violacein-synthesizing gene cluster for efficient violacein production from glycerol. Biochem Eng J. 2011;57(1):55-62. https://doi.org/10.1016/j.bej.2011.08.008.

52. Khanna S, Goyal A, Moholkar VS. Production of n-butanol from biodiesel derived crude glycerol using Clostridium pasteurianum immobilized on Amberlite. Fuel. 2013;112:557-61. https://doi.org/10.1016/j.fuel.2011.10.071.

53. Xin F, Chen T, Jiang Y, et al. Enhanced biobutanol production with high yield from crude glycerol by acetone uncoupled Clostridium sp. strain CT7. Bioresour Technol. 2017;244:57581. https://doi.org/10.1016/j.biortech.2017.08.002.

54. González-Pajuelo M, Andrade JC, Vasconcelos I. Production of 1,3-propanediol by Clostridium butyricum VPI 3266 using a synthetic medium and raw glycerol. J Ind Microbiol Biotechnol. 2004;31(9):442-6. https://doi.org/10.1007/ s10295-004-0168-z.

55. Mendes FS, González-Pajuelo M, Cordier H, François JM, Vasconcelos I. 1,3-Propanediol production in a two-step process fermentation from renewable feedstock. Appl Microbiol Biotechnol. 2011;92(3):519-27. https://doi.org/10.1007/s00253-011-3369-1.

56. Wang X-L, Zhou J-J, Shen J-T, Zheng Y-F, Sun Y, Xiu Z-L. Sequential fed-batch fermentation of 1, 3-propanediol from glycerol by Clostridium butyricum DL07. Appl Microbiol Biotechnol. 2020;104(21):9179-91.

57. Boonyawanich S, Haosagul S, Pisutpaisal N. Ethanol production from waste glycerol using glucose as co-carbon source. Biomass Convers Biorefin. 2021. https://doi.org/10.1007/s13399-02101325-z (Published online February 5, 2021:1-10).

58. Kongjan P, Jariyaboon R, Reungsang A, Sittijunda S. Co-fermentation of 1,3-propanediol and 2,3-butanediol from crude glycerol derived from the biodiesel production process by newly isolated Enterobacter sp.: optimization factors affecting. Bioresour Technol Reports. 2021;13:616. https://doi.org/10.1016/j.biteb.2020. 100616.

59. Podleśny M, Wyrostek J, Kucharska J, Jarocki P, KomońJanczara E, Targoński Z. A New Strategy for Effective Succinic Acid Production by Enterobacter sp. LU1 Using a Medium Based on Crude Glycerol and Whey Permeate. molecules. 2019. https:// doi.org/10.3390/molecules24244543.

60. Soo CS, Yap WS, Hon WM, Ramli N, Md Shah UK, Phang LY. Co-production of hydrogen and ethanol by Escherichia coli
SS1 and its recombinant. Electron J Biotechnol. 2017;30:64-70. https://doi.org/10.1016/j.ejbt.2017.09.002.

61. Cheng KK, Zeng J, Jian JH, Zhu JF, Zhang GX, Liu DH. Modelbased temperature control for improving lactic acid production from glycerol. RSC Adv. 2019;9(21):11614-20. https://doi.org/ $10.1039 / \mathrm{c} 9 \mathrm{ra} 01323 \mathrm{~g}$.

62. Li Y, Li M, Zhang X, Yang P, Liang Q, Qi Q. A novel wholephase succinate fermentation strategy with high volumetric productivity in engineered Escherichia coli. Bioresour Technol. 2013;149:333-40. https://doi.org/10.1016/j.biortech.2013.09. 077.

63. Li Q, Huang B, He Q, et al. Production of succinate from simply purified crude glycerol by engineered Escherichia coli using twostage fermentation. Bioresour Bioprocess. 2018;5(1):41. https:// doi.org/10.1186/s40643-018-0227-3.

64. Yu Y, Zhu X, Xu H, Zhang X. Construction of an energyconserving glycerol utilization pathways for improving anaerobic succinate production in Escherichia coli. Metab Eng. 2019;56:181-9. https://doi.org/10.1016/j.ymben.2019.10.002.

65. Saini M, Wang ZW, Chiang CJ, Chao YP. Metabolic engineering of Escherichia coli for production of n-butanol from crude glycerol. Biotechnol Biofuels. 2017;10(1):173. https://doi.org/ 10.1186/s13068-017-0857-2.

66. Oh BR, Heo SY, Lee SM, et al. Production of 2-butanol from crude glycerol by a genetically-engineered Klebsiella pneumoniae strain. Biotechnol Lett. 2014;36(1):57-62. https://doi.org/ 10.1007/s10529-013-1333-0.

67. Zhao YN, Chen G, Yao SJ. Microbial production of 1,3-propanediol from glycerol by encapsulated Klebsiella pneumoniae. Biochem Eng J. 2006;32(2):93-9. https://doi.org/10.1016/j.bej. 2006.09.007.

68. Yang G, Tian J, Li J. Fermentation of 1,3-propanediol by a lactate deficient mutant of Klebsiella oxytoca under microaerobic conditions. Appl Microbiol Biotechnol. 2007;73(5):1017-24. https:// doi.org/10.1007/s00253-006-0563-7.

69. Xu Y-Z, Guo N-N, Zheng Z-M, Ou X-J, Liu H-J, Liu D-H. Metabolism in 1,3-propanediol fed-batch fermentation by a D-lactate deficient mutant of Klebsiella pneumoniae. Biotechnol Bioeng. 2009;104(5):965-72. https://doi.org/10.1002/bit.22455.

70. Zhang Y, Li Y, Du C, Liu M, Cao Z. Inactivation of aldehyde dehydrogenase: a key factor for engineering 1,3-propanediol production by Klebsiella pneumoniae. Metab Eng. 2006;8(6):57886. https://doi.org/10.1016/j.ymben.2006.05.008.

71. Laura M, Monica T, Dan-Cristian V. The effect of crude glycerol impurities on 1,3-propanediol biosynthesis by Klebsiella pneumoniae DSMZ 2026. Renew Energy. 2020;153:1418-27. https:// doi.org/10.1016/j.renene.2020.02.108.

72. Ju JH, Wang D, Heo SY, et al. Enhancement of 1,3-propanediol production from industrial by-product by Lactobacillus reuteri CH53. Microb Cell Fact. 2020;19(1):6. https://doi.org/10.1186/ s12934-019-1275-x.

73. Zhang A, Yang ST. Propionic acid production from glycerol by metabolically engineered Propionibacterium acidipropionici. Process Biochem. 2009;44(12):1346-51. https://doi.org/10. 1016/j.procbio.2009.07.013.

74. Mabutyana L, Pott RW. Photo-fermentative hydrogen production by Rhodopseudomonas palustris CGA009 in the presence of inhibitory compounds. Int J Hydrogen Energy. 2021. https://doi. org/10.1016/j.ijhydene.2020.12.189 (Published online January 21, 2021).

75. Gupta A, Murarka A, Campbell P, Gonzalez R. Anaerobic fermentation of glycerol in Paenibacillus macerans: metabolic pathways and environmental determinants. Appl Environ Microbiol. 2009;75(18):5871-83. https://doi.org/10.1128/AEM.01246-09.

76. André A, Diamantopoulou P, Philippoussis A, Sarris D, Komaitis M, Papanikolaou S. Biotechnological conversions of 
bio-diesel derived waste glycerol into added-value compounds by higher fungi: production of biomass, single cell oil and oxalic acid. Ind Crops Prod. 2010;31(2):407-16. https://doi. org/10.1016/j.indcrop.2009.12.011.

77. Singh A, Abidi AB, Agrawal AK, Darmwal NS. Single cell protein production by Aspergillus niger and its evaluation. Zentralbl Mikrobiol. 1991;146(3):181-4. https://doi.org/10. 1016/s0232-4393(11)80178-2.

78. Moustogianni A, Bellou S, Triantaphyllidou I-E, Aggelis G. Feasibility of raw glycerol conversion into single cell oil by zygomycetes under non-aseptic conditions. Biotechnol Bioeng. 2015;112(4):827-31. https://doi.org/10.1002/bit.25482.

79. Yu KO, Kim SW, Han SO. Engineering of glycerol utilization pathway for ethanol production by Saccharomyces cerevisiae. Bioresour Technol. 2010;101(11):4157-61. https://doi.org/10. 1016/j.biortech.2010.01.066.

80. Liang Y, Cui Y, Trushenski J, Blackburn JW. Converting crude glycerol derived from yellow grease to lipids through yeast fermentation. Bioresour Technol. 2010;101(19):7581-6. https:// doi.org/10.1016/j.biortech.2010.04.061.

81. Li C, Gao S, Yang X, Lin CSK. Green and sustainable succinic acid production from crude glycerol by engineered Yarrowia lipolytica via agricultural residue based in situ fibrous bed bioreactor. Bioresour Technol. 2018;249:612-9. https://doi.org/ 10.1016/j.biortech.2017.10.011.

82. Thiru M, Sankh S, Rangaswamy V. Process for biodiesel production from Cryptococcus curvatus. Bioresour Technol. 2011;102(22):10436-40. https://doi.org/10.1016/j.biortech. 2011.08.102.

83. Yen HW, Yang YC, Yu YH. Using crude glycerol and thin stillage for the production of microbial lipids through the cultivation of Rhodotorula glutinis. J Biosci Bioeng. 2012;114(4):453-6. https://doi.org/10.1016/j.jbiosc.2012.04. 022 .

84. Lung YT, Tan CH, Show PL, et al. Docosahexaenoic acid production from crude glycerol by Schizochytrium limacinum SR21. Clean Technol Environ Policy. 2016;18(7):2209-16. https://doi.org/10.1007/s10098-016-1126-y.

85. Valentin Popa, Irina Volf. Biomass as Renewable Raw Material to Obtain Bioproducts of High-Tech Value - 1st Edition 2018. Edited by Irina Volf Valentin Popa. 1st ed. Elsevier.

86. Breuer M, Ditrich K, Habicher T, et al. Industrial Methods for the Production of Optically Active Intermediates. Angew Chemie Int Ed. 2004;43(7):788-824. https://doi.org/10.1002/ anie. 200300599.

87. Kumar S, Singh N, Prasad R. Anhydrous ethanol: A renewable source of energy. Renew Sustain Energy Rev. 2010;14(7):1830-44. https://doi.org/10.1016/j.rser.2010.03. 015 .

88. Souza WLR, Silva CS, Meleiro LAC, Mendes MF. Ethanol dehydration in packed distillation column using glycerol as entrainer: Experiments and hetp evaluation. Brazil J Chem Eng. 2016;33(2):415-26. https://doi.org/10.1590/0104-6632.20160 332s20150341.

89. Panwar NL, Kaushik SC, Kothari S. Role of renewable energy sources in environmental protection: a review. Renew Sustain Energy Rev. 2011;15(3):1513-24. https://doi.org/10.1016/j.rser. 2010.11.037.

90. Sadh PK, Duhan S, Duhan JS. Agro-industrial wastes and their utilization using solid state fermentation: a review, vol. 5. Springer; 2018. p. 1. https://doi.org/10.1186/s40643-017-0187-z.

91. Schifter I, González U, Díaz L, Rodríguez R, Mejía-Centeno I, González-Macías C. From actual ethanol contents in gasoline to mid-blends and E-85 in conventional technology vehicles. Emission control issues and consequences. Fuel. 2018;219:239-47. https://doi.org/10.1016/j.fuel.2018.01.118.
92. Balat M, Balat H, Öz C. Progress in bioethanol processing. Prog Energy Combust Sci. 2008;34(5):551-73. https://doi.org/10. 1016/j.pecs.2007.11.001.

93. Ershov MA, Grigorieva EV, Abdellatief TMM, Chernysheva EA, Makhin DY, Kapustin VM. A new approach for producing midethanol fuels E30 based on low-octane hydrocarbon surrogate blends. Fuel Process Technol. 2021;213:106688. https://doi.org/ 10.1016/j.fuproc.2020.106688.

94. Panoutsou C, Germer S, Karka P, et al. Advanced biofuels to decarbonise European transport by 2030: markets, challenges, and policies that impact their successful market uptake. Energy Strateg Rev. 2021;34:100633. https://doi.org/10.1016/j.esr.2021. 100633.

95. Zentou H, Zainal Abidin Z, Yunus R, Awang Biak DR, Abdullah Issa M, Yahaya PM. A new model of alcoholic fermentation under a byproduct inhibitory effect. ACS Omega. 2021. https:// doi.org/10.1021/acsomega.0c04025 (Published online February 1, 2021).

96. Jervis P, Pintanel P, Hopkins K, et al. Post-epizootic microbiome associations across communities of neotropical amphibians. Mol Ecol. 2021;30(5):1322-35. https://doi.org/10.1111/mec.15789.

97. Baruah J, Nath BK, Sharma R, et al. Recent trends in the pretreatment of lignocellulosic biomass for value-added products. Front Energy Res. 2018;6:141. https://doi.org/10.3389/fenrg.2018. 00141.

98. Ahmed N, Turchini GM. The evolution of the blue-green revolution of rice-fish cultivation for sustainable food production. Sustain Sci. 2021. https://doi.org/10.1007/s11625-021-00924-z (Published online February 22, 2021:1-16).

99. Rangel AET, Reyes LH, Ramírez JMG, Barrios AFG. Optimization of glycerol consumption in wild-type Escherichia coli using central carbon modeling as an alternative approach. Biofuels Bioprod Biorefin. 2021. https://doi.org/10.1002/bbb.2205 (Published online March 4, 2021:bbb.2205).

100. Choi WJ, Hartono MR, Chan WH, Yeo SS. Ethanol production from biodiesel-derived crude glycerol by newly isolated Kluyvera cryocrescens. Appl Microbiol Biotechnol. 2011;89(4):1255-64. https://doi.org/10.1007/s00253-010-3076-3.

101. Liu X, Jensen PR, Workman M. Bioconversion of crude glycerol feedstocks into ethanol by Pachysolen tannophilus. Bioresour Technol. 2012;104:579-86. https://doi.org/10.1016/j.biortech. 2011.10.065.

102. Oh BR, Seo JW, Heo SY, et al. Efficient production of ethanol from crude glycerol by a Klebsiella pneumoniae mutant strain. Bioresour Technol. 2011;102(4):3918-22. https://doi.org/10. 1016/j.biortech.2010.12.007.

103. Adnan NAA, Suhaimi SN, Abd-Aziz S, Hassan MA, Phang LY. Optimization of bioethanol production from glycerol by Escherichia coli SS1. Renew Energy. 2014;66:625-33. https://doi.org/ 10.1016/j.renene.2013.12.032.

104. Lopes Cruz M, De Resende MM, Ribeiro EJ. Improvement of ethanol production in fed-batch fermentation using a mixture of sugarcane juice and molasse under very high-gravity conditions. Bioprocess and Biosystems Engineering 2021;44:617-25. https://doi.org/10.1007/s00449-020-02462-x.

105. Fokum E, Zabed HM, Ravikumar Y, et al. Co-fermentation of glycerol and sugars by Clostridium beijerinckii: enhancing the biosynthesis of 1,3-propanediol. Food Biosci. 2021;41:101028. https://doi.org/10.1016/j.fbio.2021.101028.

106. Oh BR, Lee SM, Heo SY, Seo JW, Kim CH. Efficient production of 1,3-propanediol from crude glycerol by repeated fedbatch fermentation strategy of a lactate and 2,3-butanediol deficient mutant of Klebsiella pneumoniae. Microb Cell Fact. 2018;17(1):92. https://doi.org/10.1186/s12934-018-0921-z.

107. Fu N, Peiris P. Co-fermentation of a mixture of glucose and xylose to ethanol by Zymomonas mobilis and Pachysolen 
tannophilus. World J Microbiol Biotechnol. 2008;24(7):1091-7. https://doi.org/10.1007/s11274-007-9613-2.

108. Oh B-R, Hong W-K, Heo S-Y, Joe M, Seo J-W, Kim CH. The role of aldehyde/alcohol dehydrogenase (AdhE) in ethanol production from glycerol by Klebsiella pneumoniae. J Ind Microbiol Biotechnol. 2013;40(2):227-33. https://doi.org/10.1007/ s10295-012-1224-8.

109. Lee SJ, Lee JH, Yang X, et al. Re-utilization of waste glycerol for continuous production of bioethanol by immobilized Enterobacter aerogenes. J Clean Prod. 2017;161:757-64. https://doi.org/10. 1016/j.jclepro.2017.05.170.

110. Nomanbhay SM, Hussain R. Immobilization of Escherichia coli mutant strain for efficient production of bioethanol from crude glycerol. J Appl Sci. 2015;15(3):415-30. https://doi.org/10.3923/ jas.2015.415.430.

111. Chanthoom K, Tanikkul P, Sirisukpoka U, Pisutpaisal N. Ethanol production form biodiesel-derived crude glycerol by Enterobacter aerogenes. Chem Eng Trans. 2016;50:211-6. https://doi.org/ 10.3303/CET1650036.

112. Prasertsan P, Leamdum C, Chantong S, Mamimin C, Kongjan $\mathrm{P}$, O-Thong S. Enhanced biogas production by co-digestion of crude glycerol and ethanol with palm oil mill effluent and microbial community analysis. Biomass Bioenergy. 2021;148:106037. https://doi.org/10.1016/j.biombioe.2021.106037.

113. Varella Rodrigues C, Oliveira Santana K, Nespeca MG, Varella Rodrigues A, Oliveira Pires L, Maintinguer SI. Energy valorization of crude glycerol and sanitary sewage in hydrogen generation by biological processes. Int J Hydrogen Energy. 2020;45(21):11943-53. https://doi.org/10.1016/j.ijhydene.2020. 02.168 .

114. Chen Y, Yin Y, Wang J. Comparison of fermentative hydrogen production from glycerol using immobilized and suspended mixed cultures. Int J Hydrogen Energy. 2021;46(13):8986-94. https://doi.org/10.1016/j.ijhydene.2021.01.003.

115. Jin ES, Lee MH, Malloy CR. The presence of 3-hydroxypropionate and 1,3-propanediol suggests an alternative path for conversion of glycerol to Acetyl-CoA. Metab Open. 2021;9:100086. https://doi.org/10.1016/j.metop.2021.100086.

116. Nazareth TC, de Oliveira Paranhos AG, Ramos LR, Silva EL. Valorization of the crude glycerol for propionic acid production using an anaerobic fluidized bed reactor with grounded tires as support material. Appl Biochem Biotechnol. 2018;186(2):40013. https://doi.org/10.1007/s12010-018-2754-y.

117. Zhang A, Sun J, Wang Z, Yang ST, Zhou H. Effects of carbon dioxide on cell growth and propionic acid production from glycerol and glucose by Propionibacterium acidipropionici. Bioresour Technol. 2015;175:374-81. https://doi.org/10.1016/j.biort ech.2014.10.046.

118. Wang Z, Ammar EM, Zhang A, Wang L, Lin M, Yang ST. Engineering Propionibacterium freudenreichii subsp. Shermanii for enhanced propionic acid fermentation: effects of overexpressing propionyl-CoA: Succinate CoA transferase. Metab Eng. 2015;27:46-56. https://doi.org/10.1016/j.ymben.2014.10.005.

119. Zhu Y, Li J, Tan M, et al. Optimization and scale-up of propionic acid production by propionic acid-tolerant Propionibacterium acidipropionici with glycerol as the carbon source. Bioresour Technol. 2010;101(22):8902-6. https://doi.org/10.1016/j.biort ech.2010.06.070.

120. Liang Y, Sarkany N, Cui Y, Blackburn JW. Batch stage study of lipid production from crude glycerol derived from yellow grease or animal fats through microalgal fermentation. Bioresour Technol. 2010;101(17):6745-50. https://doi.org/10.1016/j.biortech. 2010.03.087.

121. Chen YH, Walker TH. Biomass and lipid production of heterotrophic microalgae Chlorella protothecoides by using biodiesel-derived crude glycerol. Biotechnol Lett. 2011;33(10):1973-83. https://doi.org/10.1007/ s10529-011-0672-y.

122. Veza I, Muhamad Said MF, Latiff ZA. Recent advances in butanol production by acetone-butanol-ethanol (ABE) fermentation. Biomass Bioenerg. 2021;144:105919. https://doi.org/10. 1016/j.biombioe.2020.105919.

123. Krasňan V, Plž M, Marr AC, Markošová K, Rosenberg M, Rebroš M. Intensified crude glycerol conversion to butanol by immobilized Clostridium pasteurianum. Biochem Eng J. 2018;134:1149. https://doi.org/10.1016/j.bej.2018.03.005.

124. Chen T, Xu F, Zhang W, et al. High butanol production from glycerol by using Clostridium sp. strain CT7 integrated with membrane assisted pervaporation. Bioresour Technol. 2019;288:121530. https://doi.org/10.1016/j.biortech.2019. 121530.

125. Habe H, ShimActa Y, Fukuoka T, et al. Production of glyceric acid by Gluconobacter sp. NBRC3259 using raw glycerol. Biosci Biotechnol Biochem. 2009;73(8):1799-805. https://doi.org/10. 1271/bbb. 90163 .

126. Kumar LR, Yellapu SK, Yan S, Tyagi RD, Drogui P. Elucidating the effect of impurities present in different crude glycerol sources on lipid and citric acid production by Yarrowia lipolytica SKY7. J Chem Technol Biotechnol. 2021;96(1):227-40. https://doi.org/ 10.1002/jctb.6531.

127. Rzechonek DA, Dobrowolski A, Rymowicz W, Mirończuk AM. Aseptic production of citric and isocitric acid from crude glycerol by genetically modified Yarrowia lipolytica. Bioresour Technol. 2019;271:340-4. https://doi.org/10.1016/j.biortech.2018.09. 118.

128. Monnard CR, Dulloo AG. Polyunsaturated fatty acids as modulators of fat mass and lean mass in human body composition regulation and cardiometabolic health. Obes Rev. 2021. https:// doi.org/10.1111/obr. (13197 Published online January 20, 2021:e13197).

129. Anthony R, Macartney MJ, Peoples GE. The influence of longchain omega-3 fatty acids on eccentric exercise-induced delayed muscle soreness: reported outcomes are compromised by study design issues. Int J Sport Nutr Exerc Metab. 2021;31(2):1-11. https://doi.org/10.1123/ijsnem.2020-0238.

130. Oguro A, Ishihara Y, Siswanto FM, et al. Contribution of DHA diols (19,20-DHDP) produced by cytochrome P450s and soluble epoxide hydrolase to the beneficial effects of DHA supplementation in the brains of rotenone-induced rat models of Parkinson's disease. Biochim Biophys Acta Mol Cell Biol Lipids. 2021;1866(2):158858. https://doi.org/10.1016/j.bbalip.2020. 158858.

131. Kujawska N, Talbierz S, Dębowski M, Kazimierowicz J, Zieliński M. Optimizing docosahexaenoic acid (DHA) production by Schizochytrium sp grown on waste glycerol. Energies. 2021;14(6):1685. https://doi.org/10.3390/en14061685.

132. Ye H, He Y, Xie Y, Sen B, Wang G. Fed-batch fermentation of mixed carbon source significantly enhances the production of docosahexaenoic acid in Thraustochytriidae sp. PKU\#Mn16 by differentially regulating fatty acids biosynthetic pathways. Bioresour Technol. 2020;297:1224002. https://doi.org/10.1016/j.biort ech.2019.122402.

133. Athalye SK, Garcia RA, Wen Z. Use of biodiesel-derived crude glycerol for producing eicosapentaenoic acid (EPA) by the fungus pythium irregulare. J Agric Food Chem. 2009;57(7):273944. https://doi.org/10.1021/jf803922w.

134. Chang M, Zhang T, Li L, et al. Choreography of multiple omics reveals the mechanism of lipid turnover in Schizochytrium sp. S31. Algal Res. 2021;54:102182. https://doi.org/10.1016/j.algal. 2021.102182. 
135. Fouilloux H, Thomas CM. Production and polymerization of biobased acrylates and analogs. Macromol Rapid Commun. 2021;42(3):2000530. https://doi.org/10.1002/marc.202000530.

136. Luo X, Ge X, Cui S, Li Y. Value-added processing of crude glycerol into chemicals and polymers. Bioresour Technol. 2016;215:144-54. https://doi.org/10.1016/j.biortech.2016.03. 042.

137. Liu L, Philip YX. Nonthermal plasma induced fabrication of solid acid catalysts for glycerol dehydration to acrolein. Catalysts. 2021;11(3):1-13. https://doi.org/10.3390/catal11030391.

138. Yang Y, Zhang Y, Xie S, Tang Y, Zeng Z, Tang BZ. Hydrogelderived luminescent scaffolds for biomedical applications. Mater Chem Front. 2021;3(1):42-58. https://doi.org/10.1039/D0QM0 1140A.

139. Lu Q, Liu R, Xia G. Sequential dehydration and oxidation of biodiesel-derived crude glycerol into acrylic acid. Russ J Appl Chem. 2018;91(2):235-44. https://doi.org/10.1134/S107042721 8020118 .

140. Gallastegui A, Gabirondo E, Elizalde F, Aranburu N, Mecerreyes $\mathrm{D}$, Sardon H. Chemically recyclable glycerol-biobased polyether thermosets. Eur Polym J. 2021;143:110174. https://doi.org/10. 1016/j.eurpolymj.2020.110174.

141. Shah S, Kumar A. Production and characterization of polyhydroxyalkanoates from industrial waste using soil bacterial isolates. Brazil J Microbiol. 2021. https://doi.org/10.1007/s42770021-00452-z (Published online February 15, 2021:1-12).

142. Nikolova C, Gutierrez T. Biosurfactants and their applications in the oil and gas industry: current state of knowledge and future perspectives. Front Bioeng Biotechnol. 2021;9:626639. https:// doi.org/10.3389/fbioe.2021.626639.

143. Kumar P, Ray S, Patel SKS, Lee JK, Kalia VC. Bioconversion of crude glycerol to polyhydroxyalkanoate by Bacillus thuringiensis under non-limiting nitrogen conditions. Int J Biol Macromol. 2015;78:9-16. https://doi.org/10.1016/j.ijbiomac.2015.03.046.

144. Mohamad Fauzi AH, Chua ASM, Yoon LW, Nittami T, Yeoh HK. Enrichment of PHA-accumulators for sustainable PHA production from crude glycerol. Process Saf Environ Prot. 2019;122:200-8. https://doi.org/10.1016/j.psep.2018.12.002.

145. Mohd Zain NF, Paramasivam M, Tan JS, Lim V, Lee CK. Response surface methodology optimization of polyhydroxyalkanoate production by Burkholderia cepacia BPT1213 using waste glycerol from palm oil-based biodiesel production. Biotechnol Prog. 2021. https://doi.org/10.1002/btpr.3077.

146. Liu MH, Chen YJ, Lee CY. Characterization of medium-chainlength polyhydroxyalkanoate biosynthesis by Pseudomonas mosselii TO7 using crude glycerol. Biosci Biotechnol Biochem. 2018;82(3):532-9. https://doi.org/10.1080/09168451.2017. 1422386 .

147. Kumar LR, Kaur R, Tyagi RD, Drogui P. Identifying economical route for crude glycerol valorization: biodiesel versus polyhydroxy-butyrate (PHB). Bioresour Technol. 2021;323:124565. https://doi.org/10.1016/j.biortech.2020. 124565 .

148. Naranjo JM, Posada JA, Higuita JC, Cardona CA. Valorization of glycerol through the production of biopolymers: the PHB case using Bacillus megaterium. Bioresour Technol. 2013;133:38-44. https://doi.org/10.1016/j.biortech.2013.01.129.

149. Freches A, Lemos PC. Microbial selection strategies for polyhydroxyalkanoates production from crude glycerol: Effect of OLR and cycle length. N Biotechnol. 2017;39:22-8. https://doi.org/ 10.1016/j.nbt.2017.05.011.

150. Chaitanya Reddy C, Khilji IA, Gupta A, et al. Valorization of keratin waste biomass and its potential applications. J Water Process Eng. 2021;40:101707. https://doi.org/10.1016/j.jwpe.2020. 101707.

151. Chilakamarry CR, Mahmood S, Saffe SNBM, et al. Extraction and application of keratin from natural resources: a review. 3 Biotech. 2021;11(5):220. https://doi.org/10.1007/ s13205-021-02734-7.

152. Bodík I, Blšláková $\mathrm{A}$, Sedláček $\mathrm{S}$, Hutňan M. Biodiesel waste as source of organic carbon for municipal WWTP denitrification. Bioresour Technol. 2009;100(8):2452-6. https://doi.org/10. 1016/j.biortech.2008.11.050.

153. Fountoulakis MS, Petousi I, Manios T. Co-digestion of sewage sludge with glycerol to boost biogas production. Waste Manag. 2010;30(10):1849-53. https://doi.org/10.1016/j.wasman.2010. 04.011 .

154. Konrad O, Koch FF, Lumi M, Tonetto JF, Bezama A. Potential of biogas production from swine manure supplemented with glycerine waste. Eng Agric. 2014;34(5):844-53. https://doi.org/10. 1590/S0100-69162014000500004.

155. da César AS, Werderits DE, de Oliveira Saraiva GL, Guabiroba da RCS. . The potential of waste cooking oil as supply for the Brazilian biodiesel chain. Renew Sustain Energy Rev. 2017;72:246-53. https://doi.org/10.1016/j.rser.2016.11.240.

156. Carcò G, Gallo L, Dalla Bona M, Latorre MA, Fondevila M, Schiavon S. The influence of feeding behaviour on growth performance, carcass and meat characteristics of growing pigs. Óvilo C, ed. PLoS ONE. 2018;13(10):e02055772. https://doi.org/10. 1371/journal.pone.0205572.

157. Rossi M, Pina CD, Pagliaro M, Ciriminna R, Forni P. Greening the construction industry: enhancing the performance of cements by adding bioglycerol. Chem Sus chem. 2008;1(10):809-12. https://doi.org/10.1002/cssc.200800088.

158. Parvulescu A, Rossi M, Pina CD, Ciriminna R, Pagliaro M. Investigation of glycerol polymerization in the clinker grinding process. Green Chem. 2011;13(1):143-8. https://doi.org/10. 1039/c0gc00107d. 